\title{
الحذف واثره في التوسع الدلالي في آيات الإرشاد والتحذير
}

أ.م.د. عزيز سليم علي القربشي

كلية التربية / جامعة واسط

المعروف أن الحذف هو أسلوب نحوي ,وهو من الأساليب التركيبية التي تدخل في باب علم المعاني, التي

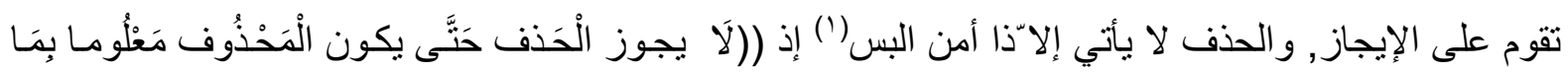

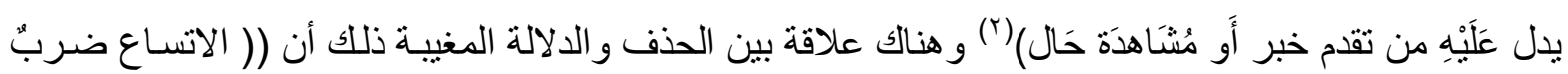

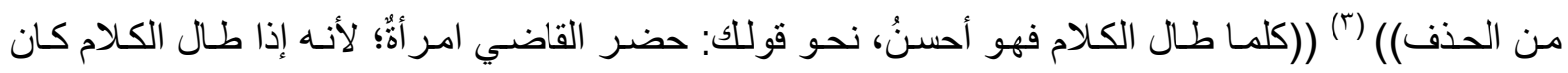

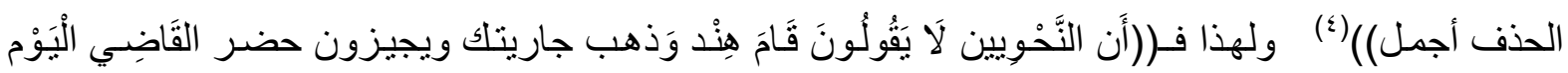

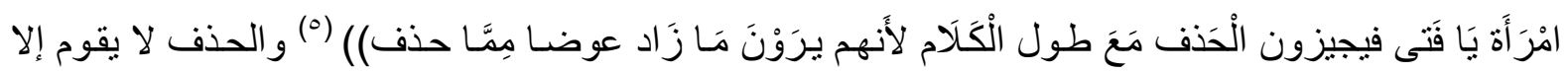

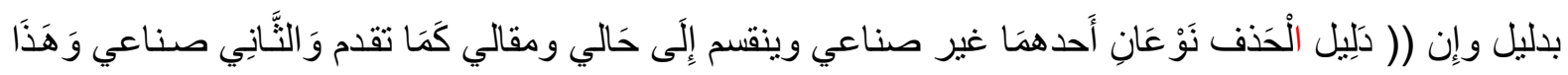

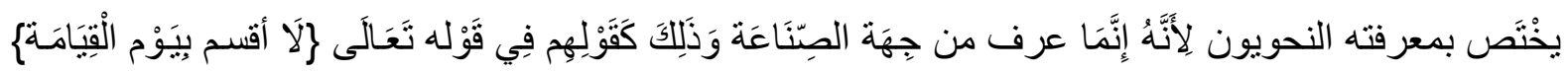

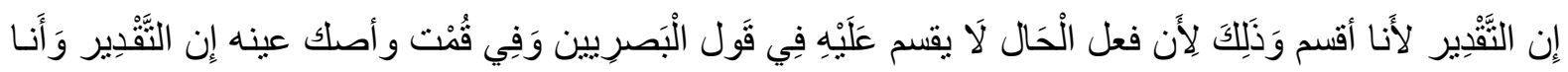

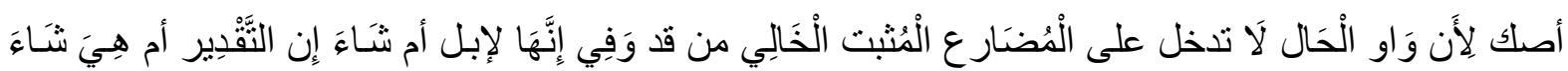

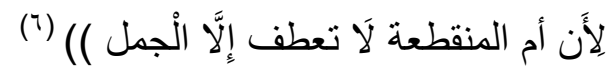

و المعروف أن الإيجاز يقوم على اختصار الكلام وتغييب أجزاء منه قد تصل إلى جمل متعددة, بيد أن هذا الإخفاء و الإضمار يحمل ور اءه الكثير من الدلالات التي تزيد كثيرا على الجزء المغيب الذي قد يقدر بكلمة. و الأمر أبعد من ذلك, ولو بقي الجزء المغيب, لمـا استطاعت الدلالة الكاملة الوصول للمتلقي, وقد قام الباحث على اختيار موضوع الإرشاد و التحذير القرآني ؛ لأن فيه الكثير من الحذف القائم على إضمار أثنياء كثيرة ,

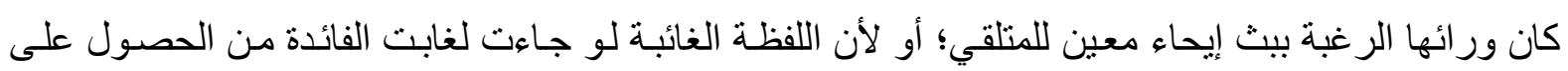
دلالات كثيرة قابعة خلفها, و هذا كله داخل في بـاب الإيجاز القرآني, الذي دخل في الإرشـاد وبـاب الإعجـاز القر آنـي (وقد اهنّم علمـاءُ البلاغـة، و البـاحثون في إعجـاز القرآن بدر اسـة مـا في كتـاب الله مـن محذوفات، وبدر اسة أقوال كِبَارِ البلغاء و الفصحاء، وما فيها من عناصر محذوفة مـع إرادة توصيلِِ معانيها للمخاطبين بها، فاكتشفو ا: أنّ الحذف من صـريح البيـان، والاكتفاء بـدلائل قرائن الأحـوال أو قرائن الأقوال، أو دلائل اللّوازم

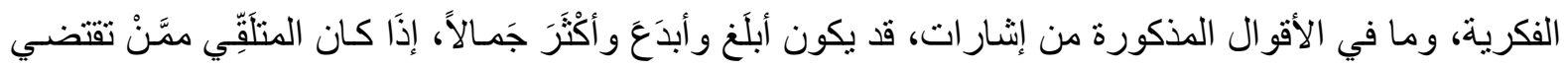

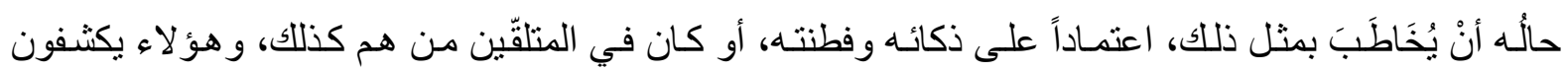

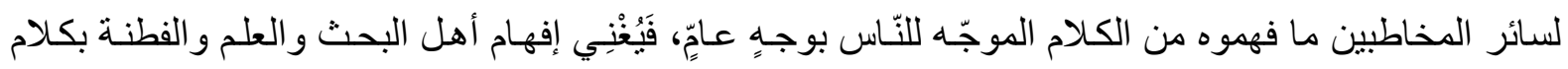

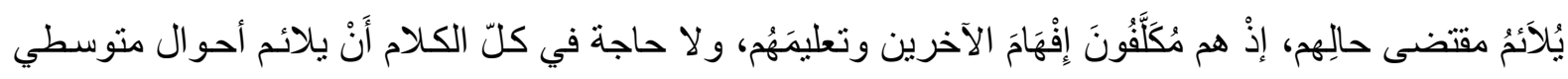

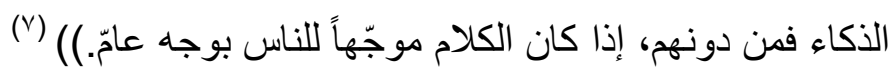

و الحذف جزء مهم في اللغـة العربيـة ((وعـادة العرب الحذف إذا كـان فيمـا بقي دليلا على مـا حذف)) (^) و المعروف أن (( القول في الحذف على ثلاثنة محساور رئيسـة: الأول: القول في حذف جزء الجملـة. الثاني: 
القول في حذف الجملة. الثالث: القول في حذف أكثر من جملة.))(9) وهو أنواع ووجوه (( منها أن تحذف

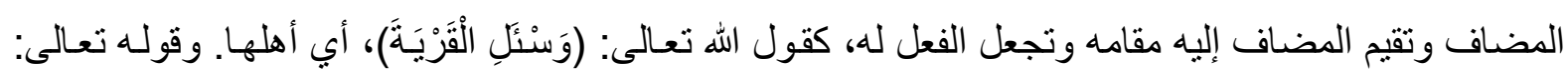

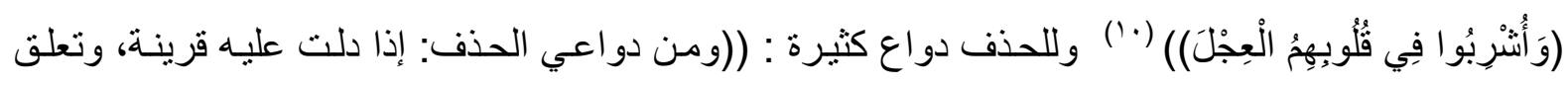
بتركه غرض من الأغر اض الآتية:

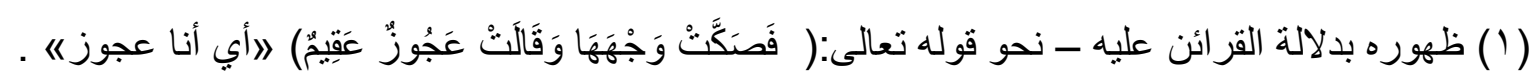
(r) إخفاءُ الأمر عن غير المخاطب ـ نحو أقبل لاثُريد عليا مثلاه .

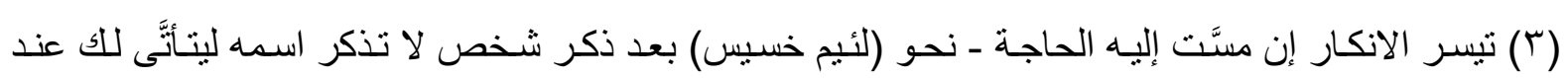
الحاجة أن تقول ما أردته و لا قصدته.

(') (') الحذر من فوات فرصة سانحة ـ كقول منبه الصياد)(

وتقوم في الحذف:(( بنية الكلام على تقليل اللفظوتكثير المعنى من غير حذف: القصر ويجعل الإيجار

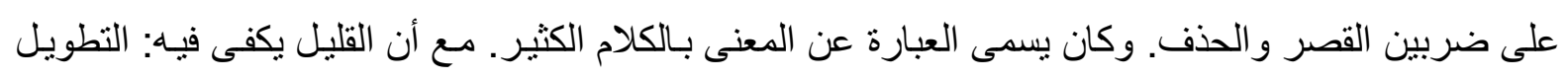

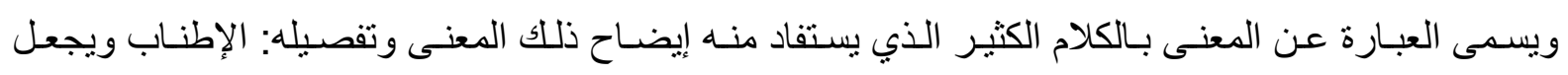

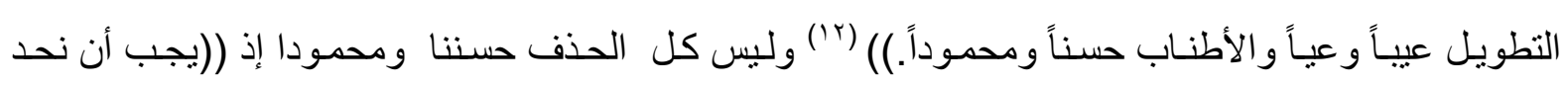
الإيجاز المحمود بأن نقول: هو إيضاح المعنى بأقل مـا يمكن من اللفظ وهذا...... إيضـاح من أن تكون العبارة

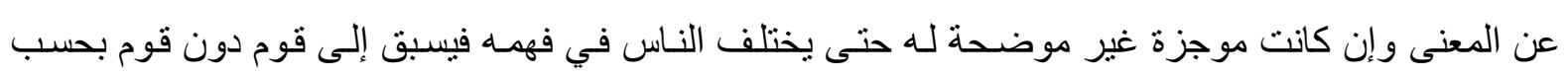
أقساطهم من الذهن وصحة التصور فإن ذلك و إن كان يستحق لفظ الإيجاز والاختصار فليس بمحمود حتى يكون

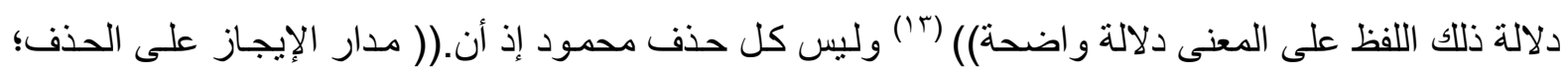
لأن موضو عه على الاختصار، وذللك إنما يكون بحذف ما لا يخل بالمعنى، و لا بنقص من البلاغة، بل أقول: لو

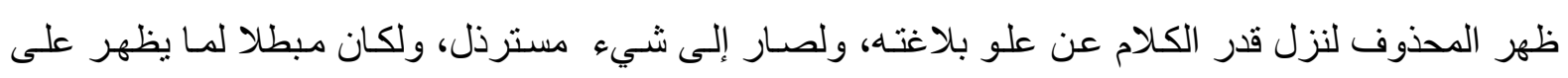
الكلام من الطلاوة و الحسن والرقة، و لابد من الدلالة على ذلك المحذوف، فإن لم يكن هنالك دلالة عليه فإنه يكون

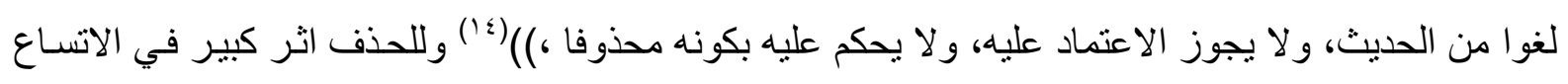

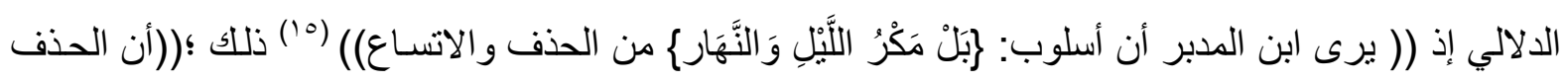

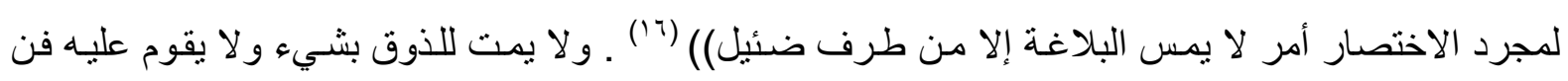
أدبي مؤثر.

وفي در استتا للحذف و الاتسـاع الدلالي الذي يقوم بـه , نرى دلالات متنوعـة, فنرى أن للحذف قدرة على الحى إحداث الإرشاد الممزوج بالتحذير وتفخيم أثره, عن طريق جعل المخاطب قادرا على تحميل دلالات كثيرة غير محصورة فيما لو قام المخاطب بالفعل الذي تم النهي عنه, كما في قوله تعالى الموجـه لآدم عليه السـلام: (وَقَقُلنَا

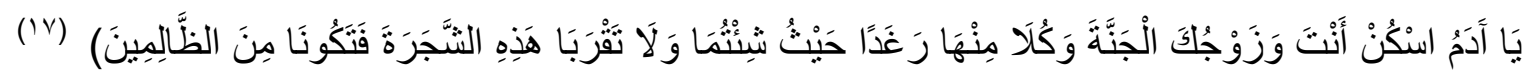




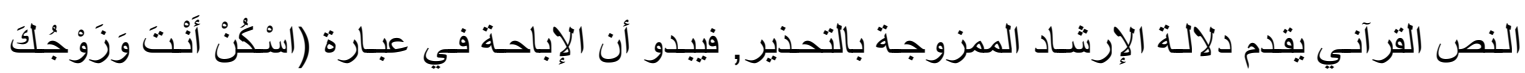

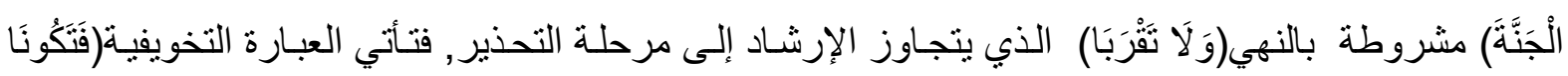

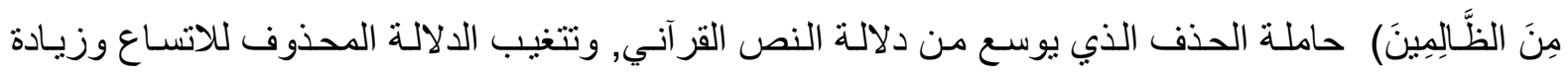

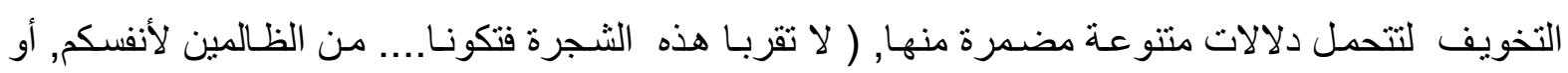
تكونا من الظالمين لأنفسكم بخروجكم من الجنة, أو لأبنائكم لنزول الأرض وذوة لترة الموت, أو لأجسامكم وأبدانكم

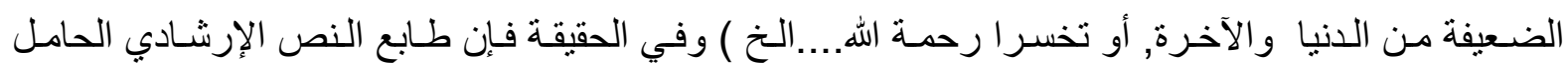
للتحذير قد عمل على إرسال الدلالة كلها عن طريق الحذف ولو جاءت لفظة واحدة وغـاب الحذف منها لما توسعت الدلالة ولما تم الإرشاد الحامل للجانب التحذيري بهذا الثكل الكبير. ومن الحذف شيئا يقوم على توسيع الدلالات, من خلال قدرة اللفظة المحذوفة على تعويم الدلالات, التي

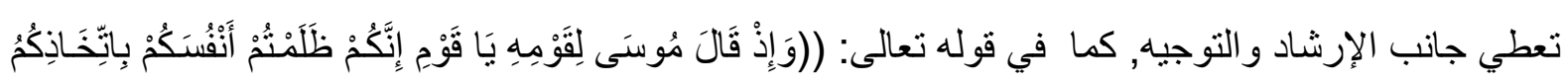

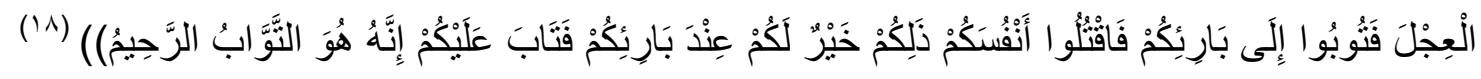

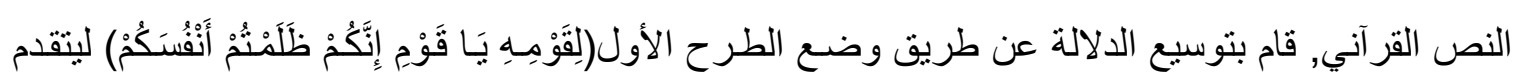

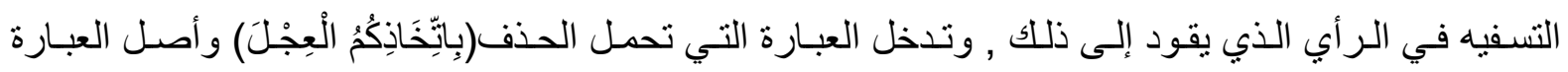

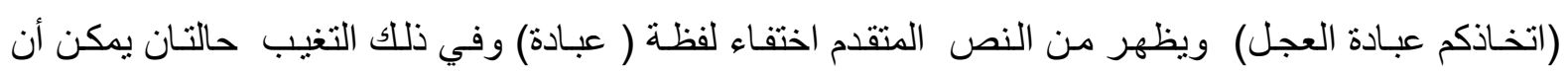

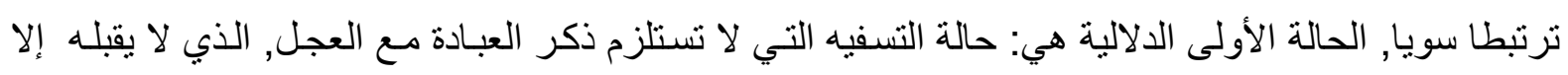

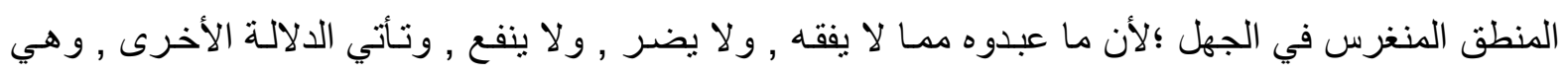

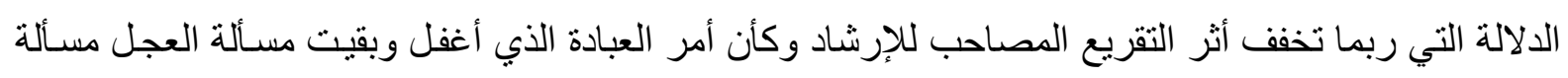
هامشية أحب النبي ( موسى ) عليه السـلام أن يشير إليها من بعيد حتى يقوم على إعادة شمل بني إسرائيل ومحاولة توجهم باليسر و الليونة الله أعلم .

ويأتي الحذف مصاحبا لصفات الله سبحانه وتعالى, لتوسيع المعـاني ,والدلالات التي تتضمنها عند ماهيـة الإرشـاد و التوجيه المصاحب للتحذير, والتي لا يمكن أن يستو عبها الذكر, كما في قوله تعـالى: ((إنَّ السَّة اصنطَفَى

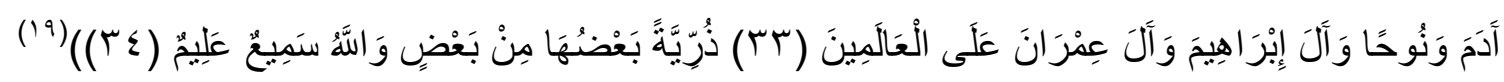
فالعبارة المتقدمة تضع الطرح المهم ( الاصطفاء , والاختيار) للأنبياء ونتأتي عبارة (سَمِيعُ عَلِيمٌ) لتتضمن المحذوف الغائب, المتعدد( فالله ـ سبحانه وتعالى ـ سميع لقول المؤمن, ولقول الكافر , ولقول المتحير أو الثـاك

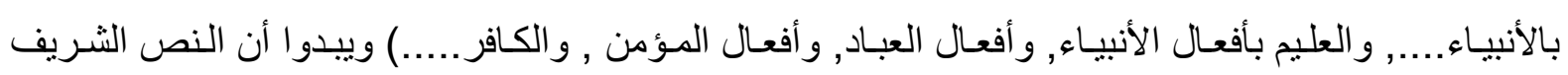

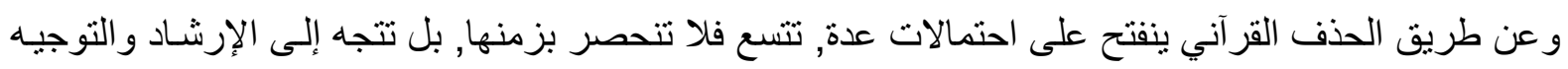

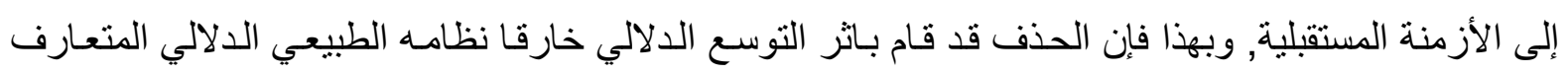
عليه الذي هو الإيجاز إلى التوسع الدلالي. وقد يأتي التوجيه و الارشاد حاملا الحذف الذي يخفي الجـار و المجرور , ليس فقط لوجود مـا يدل عليه, بـل

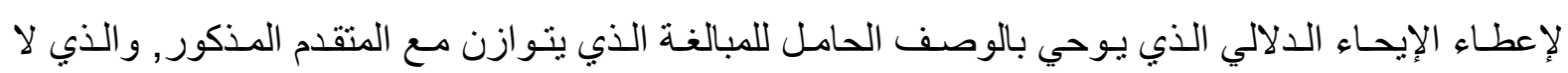


يستطيع الذكر استيعاب دلالاته المتر امية, كما في الخطاب الرباني الموجه لمريم عليها السلام: ((يَا مَرْيَمُ افْتُنِي

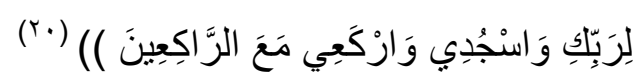

فلا يخفى أن النداء هو علامة إيحائية تفضي للانتباه للطرح المقدم لأهميته, وهو الجانب الإرشادي بضرورة القنوت و التعبد لله سبحانه وتعالى, ويبدو أن ذكر القنوت كان لز اما أن يرتبط بلفظ الجلالة, للتوضيح وللأهمية, فهو يمثل الانقطاع التام لرب العزة ولا يصح لغيره, والقنوت هو المحرك لدواخل النفس ((والقنوت يطلق بإز اء معان: قيل الطاعة، وقيل الاعاء، وبمعنى طول القيام، وبمعنى السكوت في الصـلاة.)): ('آ) وهو يعتمد على ((قوة التوكل على الله بحيث لا يلتفت القلب إلى المخلوقين في شـأن من شئونه، و لا يستشرف ولئى إليهم بقلبه،

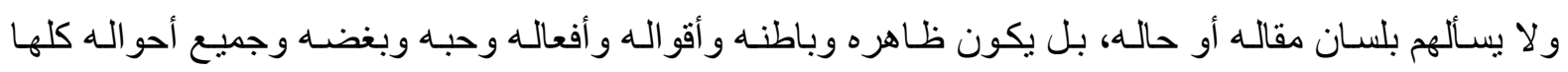

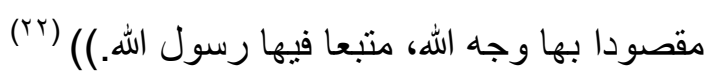

ويبدوا أن المسألة حينما تصل إلى الركوع يختفي ورائها , لفظ الجلالة ( الله) وكأن لامجال لذكر ذلك ؛ إذ

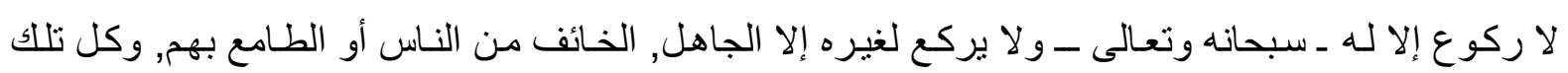
الدلالات تظهر وراء الحذف فتوسع من معناه, كذللك تختفي دلالتة التكثير و التو اصل فبالحذف يندمج( الركوع بالسجود) في حركة منو اصلة ,قوية زاد من أثرها فعل الإرشـاد الطلبي الذي جاء بـأقوى صيغ الطلب( افعل) (أقنتي , اركعي) و أكثر ها صيغة أسم الفاعل الجمعية الممتده بحرف المد الياء في( الر اكعين) وكل ذلك لم يكن ليتحقق لو جاء الذكر... و الله العالم. وكأ.

وقد يأتي النصح والإرشاد ليدل على رحمة الله التي تحبط بالمؤمنين المطيعين لله و الرسول , فياتتي الحذف دأف من خلال إظهار اللفظة التي تطوي ورائها ألفاظا ودلالات كثيرة مضمرة استطاع الإضمار احتواها , ومنه قوله لهاله

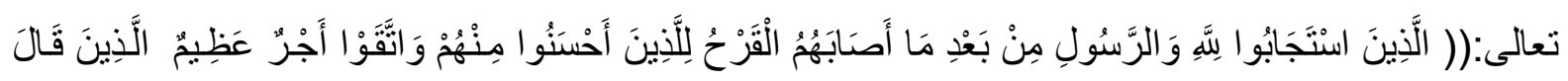

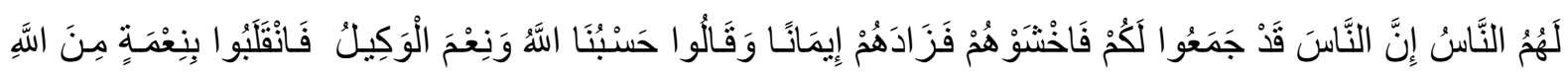

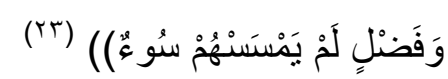

فالنص الثريف المتقدم يبين أفضلية الذين استجابوا لله والرسول, ويتبين بطريق النصسح والإرشـاد فائدة

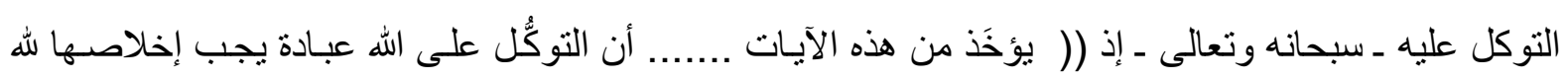

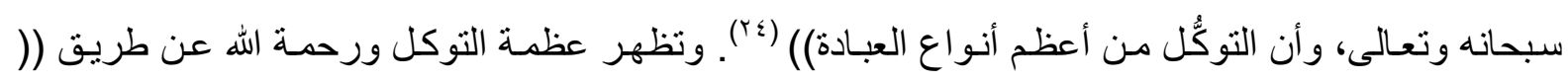

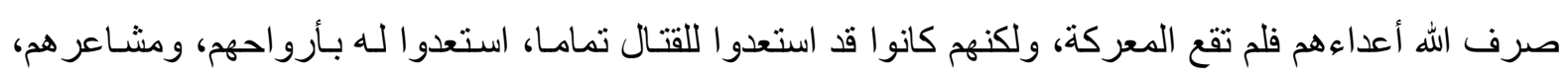
فجمعو ا عز ائمهم على الرغم من تخويف الناس لهم وعزموا على لقاء العدو متكلين على الله، وهذا هو التوكل

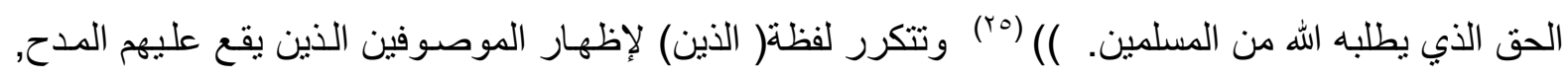
ثم تأتي عبارة( انقلبوا) لتبين سرعة التحول وماهية التغير الكبرى للخير من بعد العسر , ثم تسطع عبارة) لـ لم

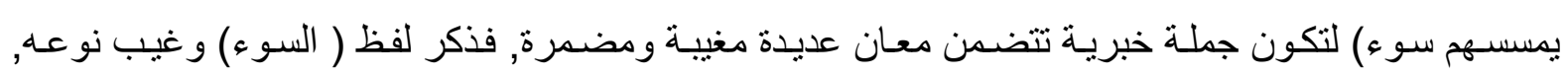

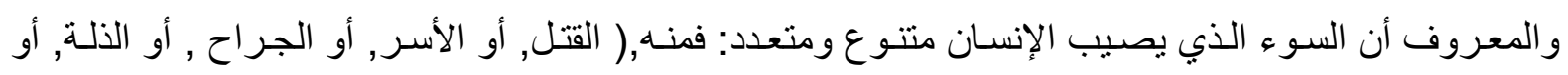

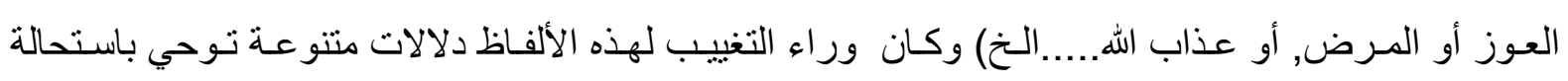

\section{$-\mu r$.}


حصر سعة رحمة الله سبحانه وتعالى بالإنسان فضلا عن الإنسان المؤمن المطيع لله, قال تعالى ((إنْْ تَعُدُوُ انِعََْةَ

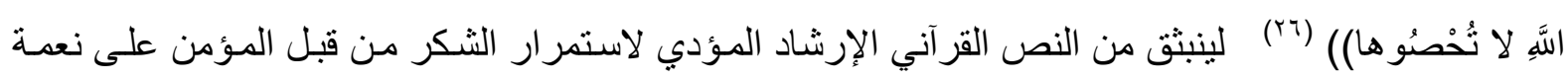
الله جل و علا. الله. ويأتي الحذف للتوسيع و الكثرة, المصاحبة للإرشاد و التوجيه, وذلك لإعطاء الثـمولية التي غاب عنها العد,

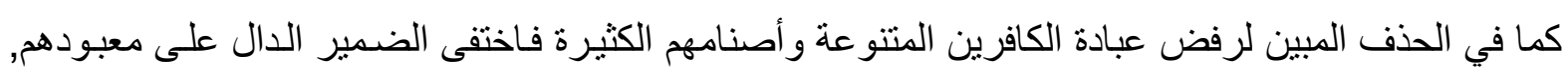

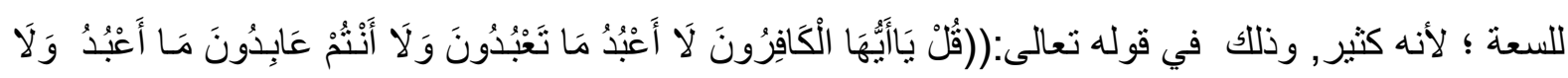

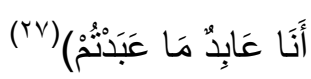

فالآية نزلت حينما طلب المشركون من النبي أن يعبد معهم آلهتهم فيعبدوا الله عز وجل فجاء الرفض من النبي ( صلى الله عليه واله وسلم) وروي في الآية:((أن سبب نزولها أن الوليد بن المغيرة , و العاص بن ولئل وائل

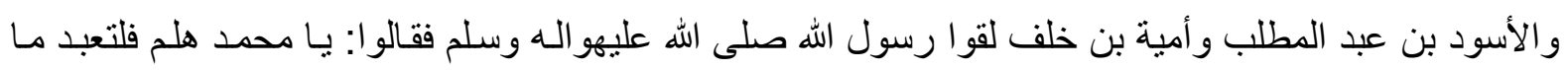

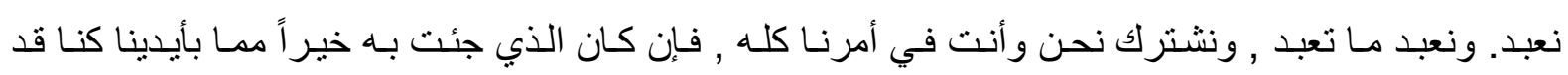

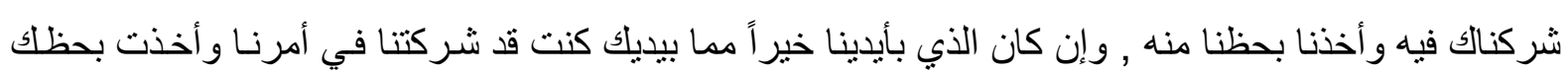

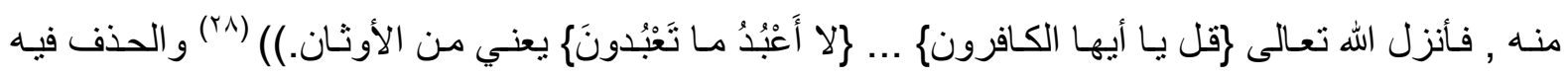

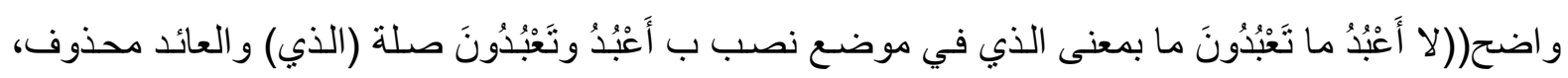

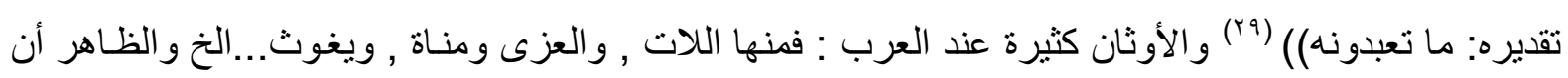
وراء الحذف هو الرفض الثامل لكل معبوداتهم.

وقد يأتي الحذف لجمل كثثرة لا يستو عبها الذكر لكثرتها وتنوعها, كما في نصح النبي صسالح عليه السـلام لقومه, ثم خالفوا أمره, فاكتفى النص القرآني بكلمـة ( قال) وترك النص مفتوحـا؛ لأن المجـال يضيق لحصره فجاء الحذف, ليبين دلالة السعة في النصح والإرشـاد الممزوج بالتحذير غير المفضـي للهدايـة, في قوله تعـالى:

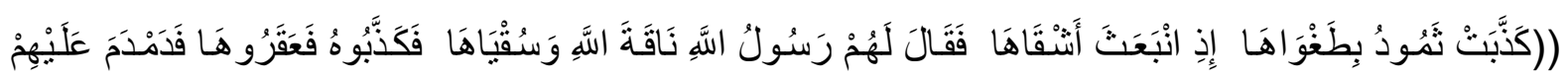

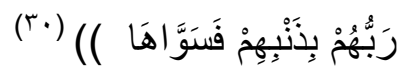

فاللفظ المتقدم هو ( كذبت) المرتبط بقوم ثمـود العاصين عن سماع الحق وقد جـاء الفعل ماضيا ليوحي بمعنى القدم والثبوت على الرغم من كثرة الهدي و النصح, ويظهر أن وراء عبارة( قال لهم رسول الله ناقة الله) ليس فقط (الزموا ناقة الله بل النبي صالح عليه السلام فقد(( بين لهم أمر الناقة وشربها وما يفعل الله- عز وجل-

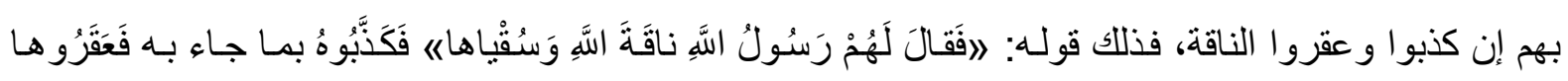
يعني قتلوا الناقة فحل بهم العذاب،)) ('آ) و التقدير المؤول( الزموا ناقة الله وسقياها) ويبدو أن الحذف أبعد من ذلك , فالعبـارة المتقدمة داخلـة في بـاب الإرشـاد الممزوج بالتحذير , وذلك يستلزم الثـيء الكثير مـن القول, فالعبارة المقدرة - و الله أعلم -( الزموا ناقة الله وسقياها وأتبعوا أمر الله فيها , والزموا القسمة و لا تخالفوا أمر الله فيصيبم العذاب إن فعلتم ذلك...) وهذا هو ديدن الأنبياء صلوات ربي عليهم أجمعين فهم يبالغون في

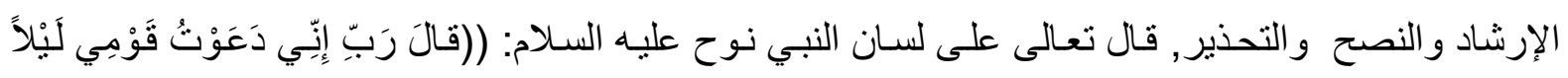




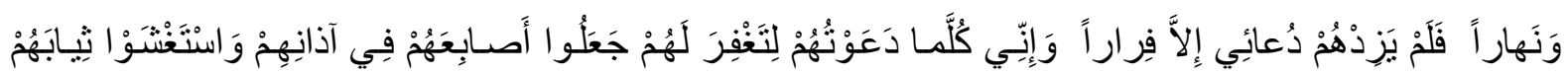

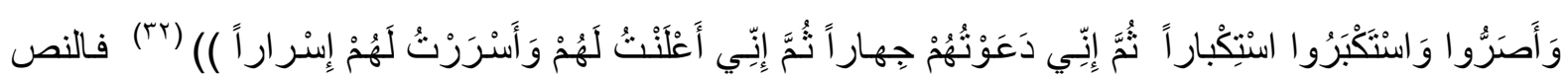
المتقدم خير دليل على كثرة ونصح الأنبياء لقومهم.

وقد باتتي النص القرآني بلفظة معينة تبين وصف معينا, بيد أن تلك اللفظة تكون عامة شمولية تخفي ور ائها

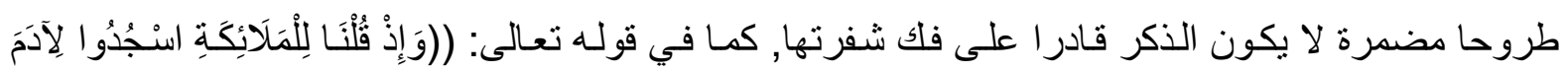

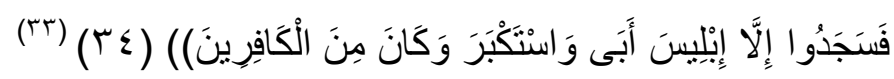

أصل العبارة (إلا ابليس أبى أن يسجد له واستكبر ضنا منه أنه أفضل من أدم عليه السلام) ويظهر أن

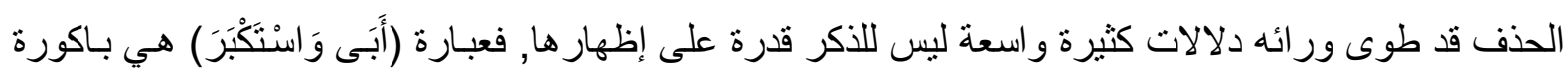

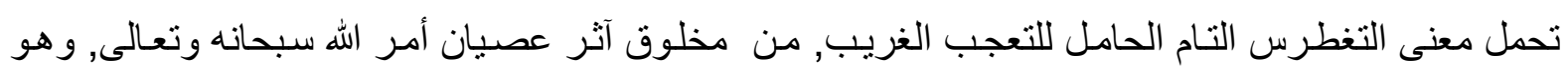

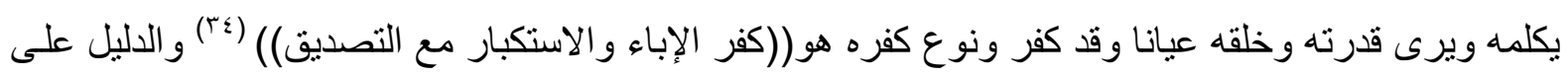

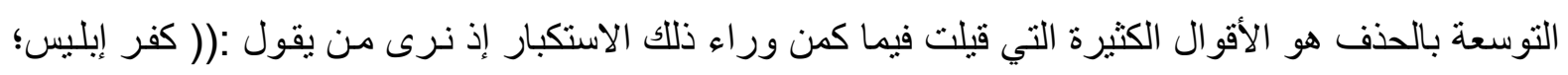

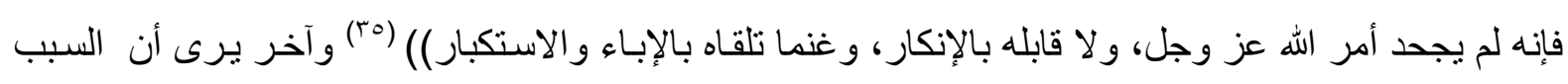

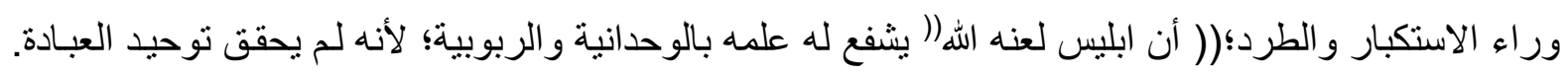

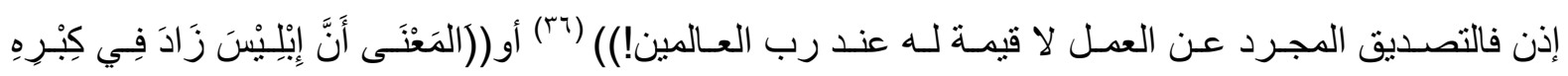

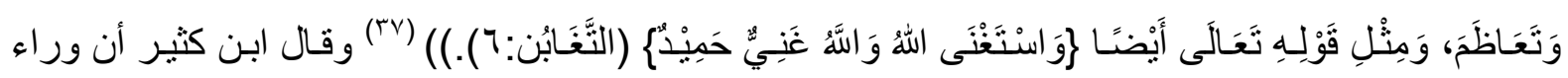

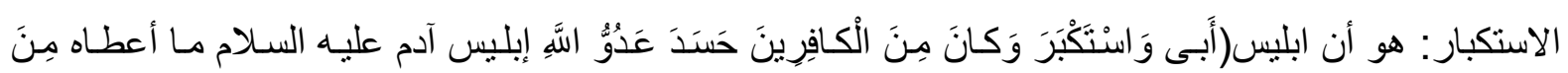

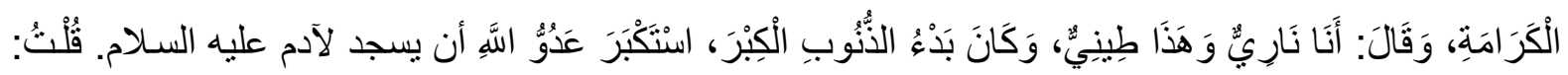

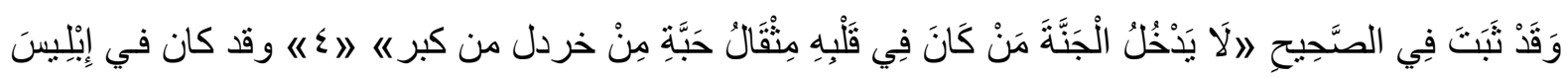

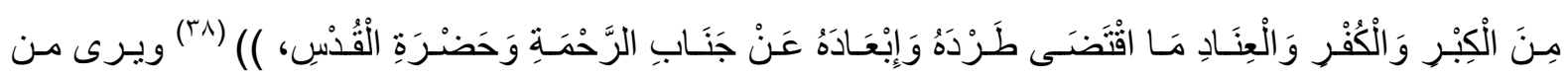

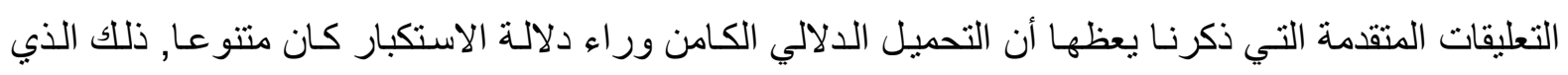
احتوته نفس - ابليس لعن الله - وهو فعلا كذلك.

وقد ترد اللفظة بالمفرد وتخفي ورائها محذوفا متتوعا, كما في لفظة ذكر النعمة الموجه لبني اسر ائيل, وهي

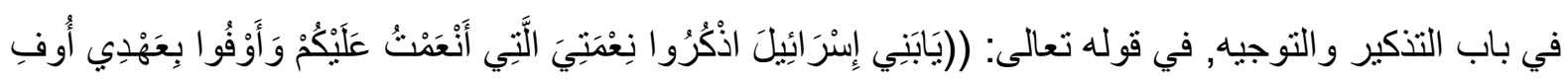

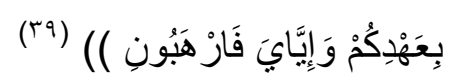

وقد أنى الحذف في النعم ليدل على ((أنها غير مُتَّاهية بحسب الأثخاص والأنواع،))(. ثُويرى الثنعراوي:

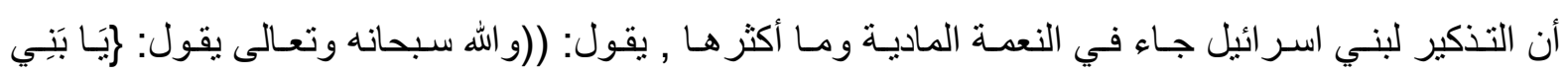

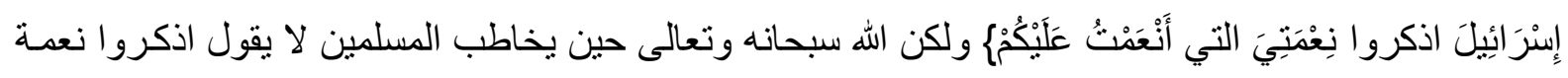

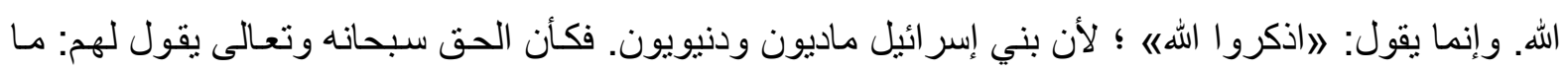

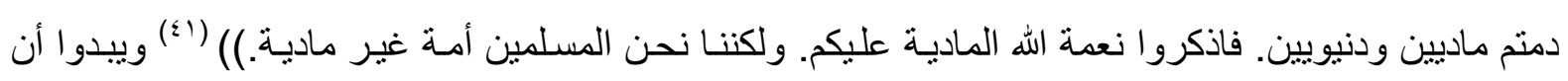

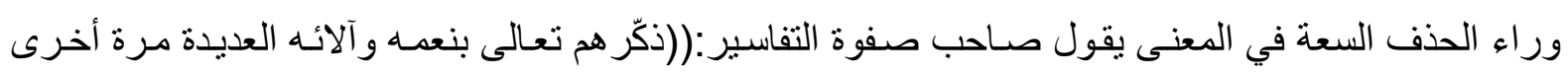




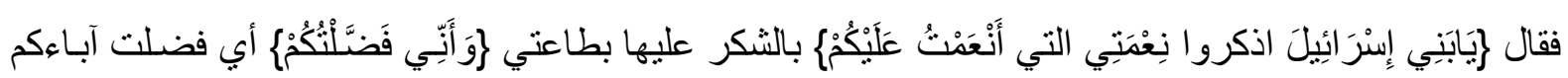

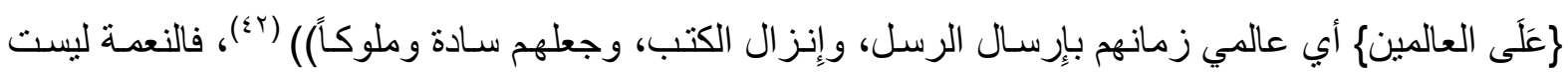
واحدة, و إنما متعددة بل لا تحصى ليست على بني اسر ائيل بل على بني أدم جمعاء, ولذا قام الحذف القابع في

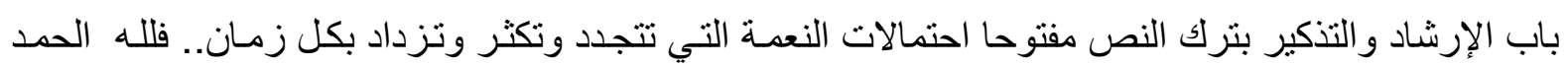
على نعمه

ويأتي الحذف ليخفي وراءه جوانب الخير الكثيرة المبعوثة لمن يخاف الله ويتبع هدى الايمـان في جانب

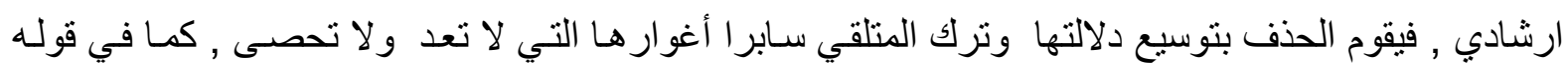

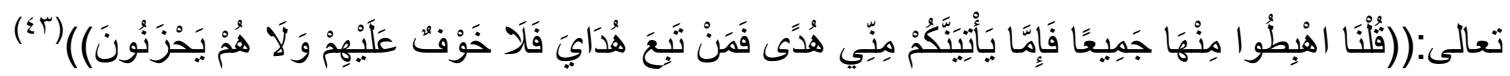

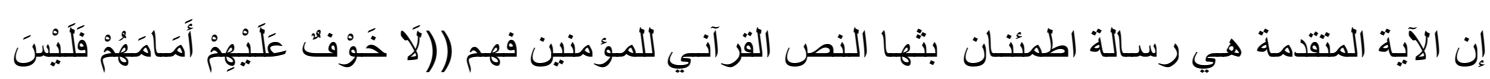

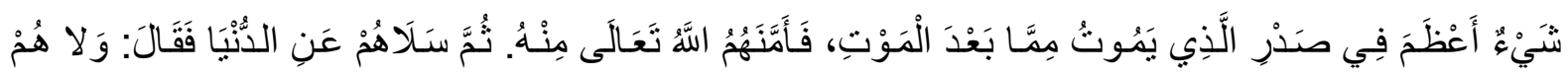

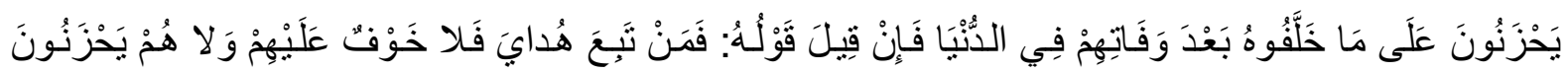

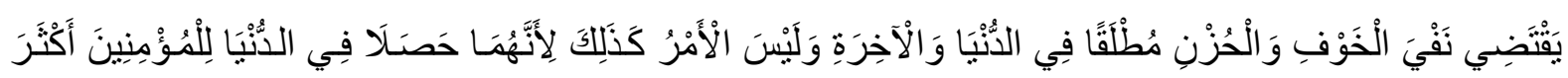

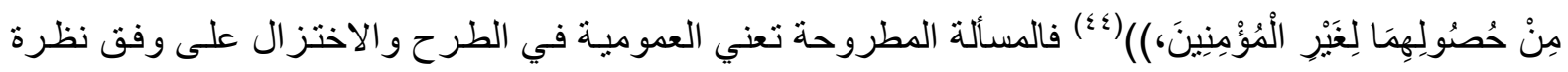

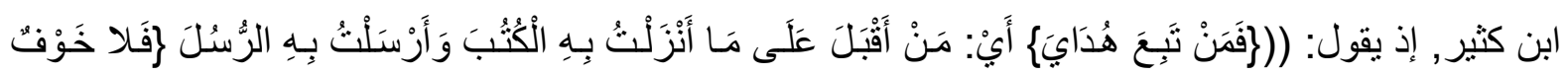

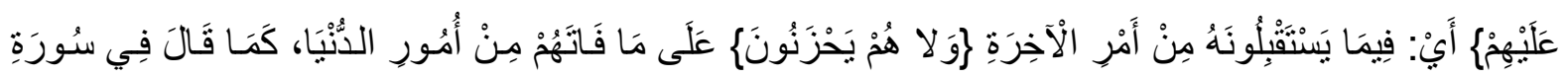

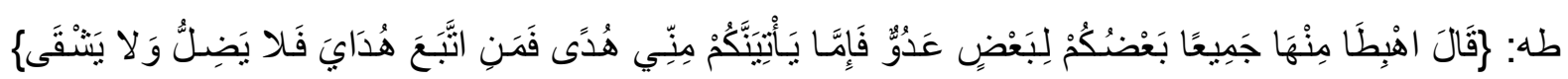

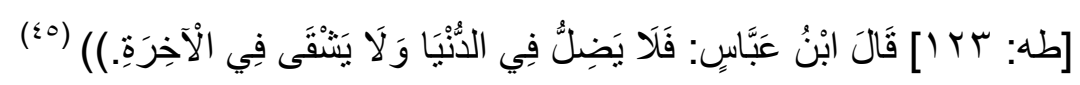

فعبارة (لا خوف عليهم) تخفي ورائها مدلو لات كثيرة تبين حسال المؤمنين وكذلك( و لاهم يحزنون) فلا

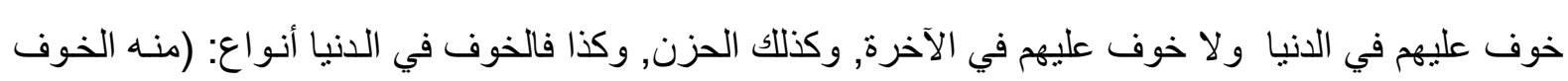

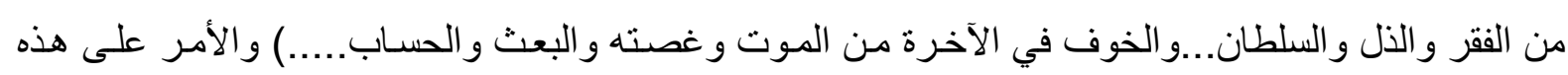
الثاكلة لا يمكن أن يقتنص بلفظة أو عبارة واحدة ؛لأنه مفتوح الدلالة ومنطور مع التطور الزمني ومثال الاختز ال الذي يبين معناه المفسرين, عبارتا( الإثم , والكفر ) التي اختزلتا دلالات كثيرة, ومنها النص

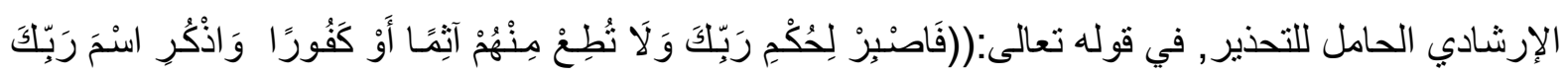

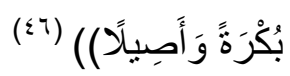

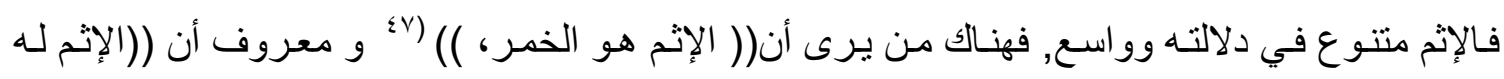

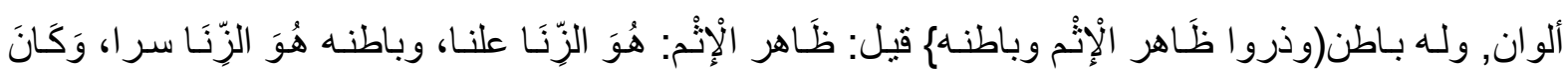

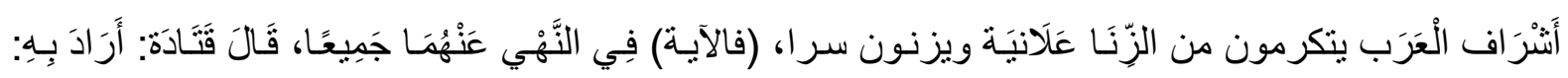

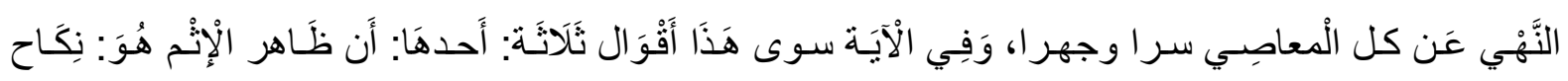

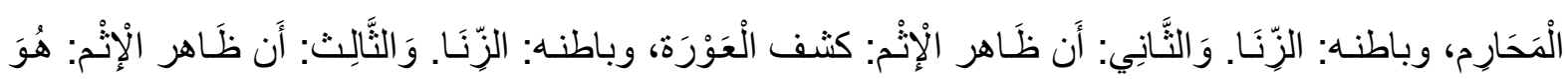




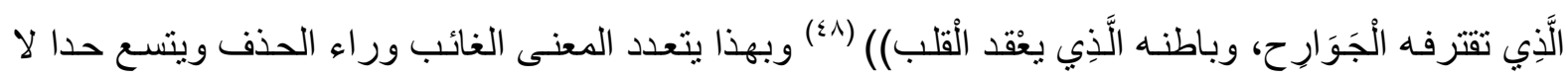
تكفله لفظة أو عبارة , فالإثم يقع في العرف الحالي على كل ما يخالف الثرع و والدين وما أكثره. ومن الحذف القرآني مـا يخلق حالـة من التهويل, تخلقها صسورة مشـهديه مغيبـة, لا يستطيع الذكر وضـع أطر ها فيصبح الحذف الحالة المثالية الموحية باتساع ألو انها, كما في وصف أهوال يوم القيامة ووقوف الكافرين على أعتابها, في صورة تتدرج بين التهويل والتحذير, مع مسحة من الإرشـاد المفضي للعمل على الابتعاد عن باتِ

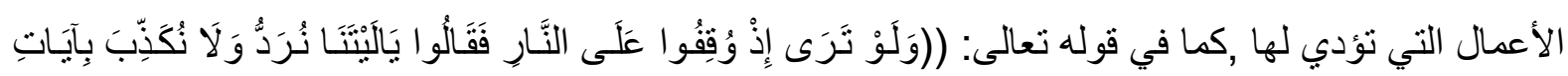

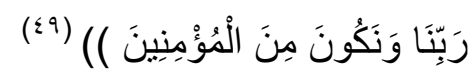

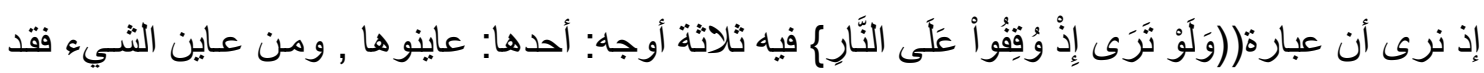

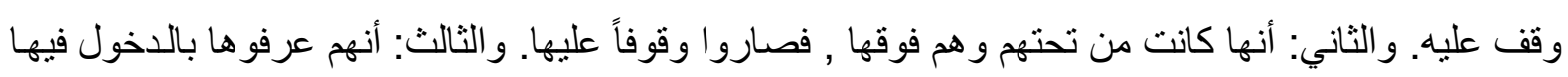

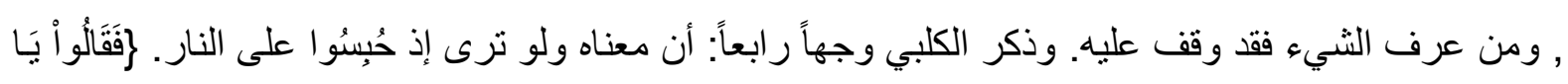

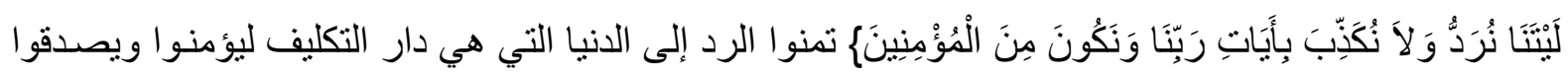

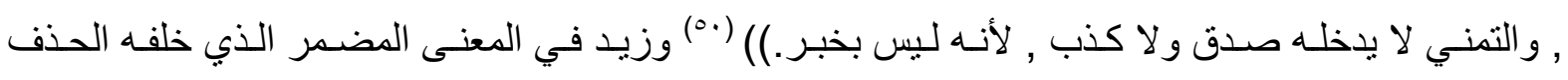

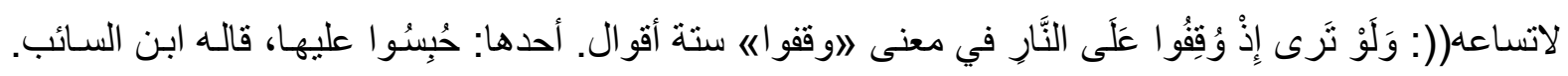

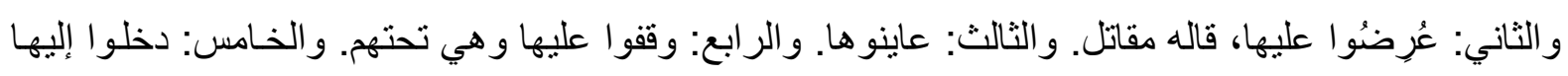

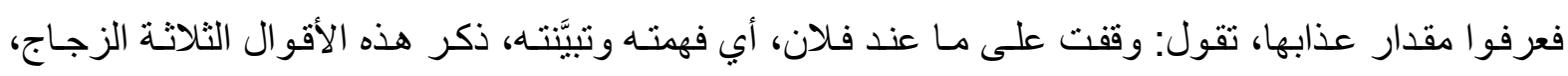

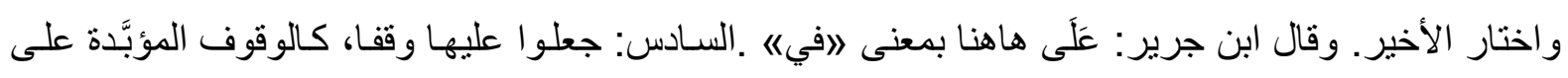

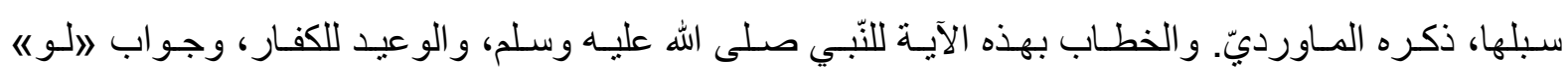

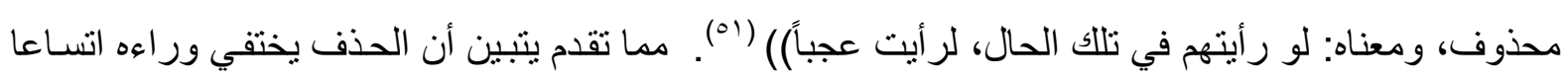

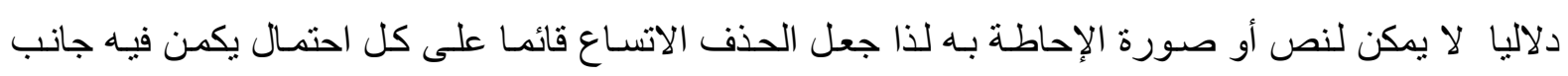
التهويل, لتصعد جذوة التحذير. عاذنا الله من شرور ذلك اليوم وأهو اله.

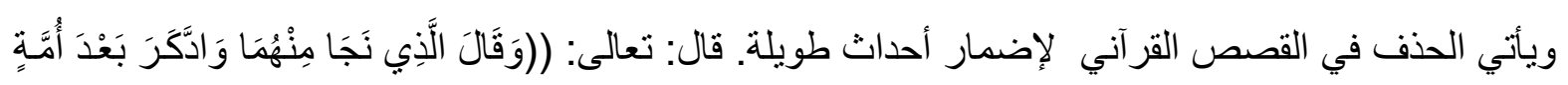

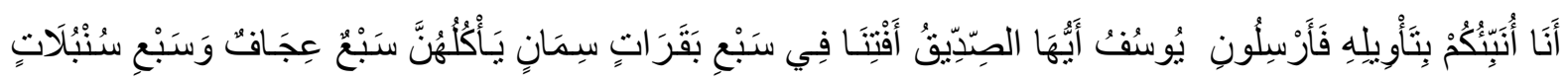

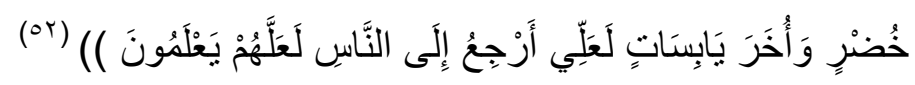

النص هو من قبيل النصح والإرشاد, الذي وجهه ساقي فرعون له في تفسير الحلم , ويأتي الحذف لاختزال المشهد لسعته عن طريق عبار ات محذوفة, فالعبارة المحذوفة عند الطبري هي((قول الله: (وادّكر بعد أمسة) ، أي

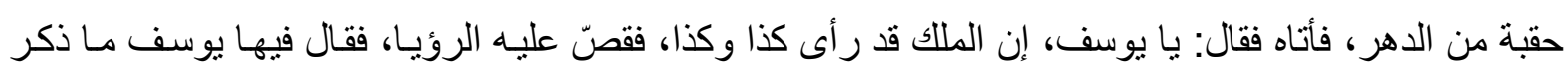

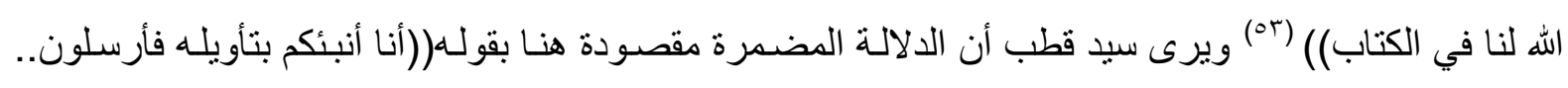

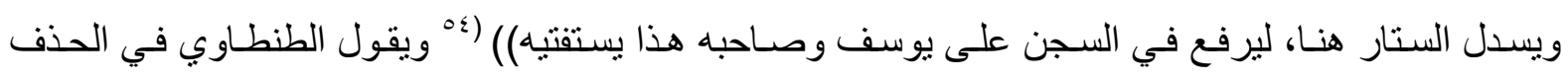

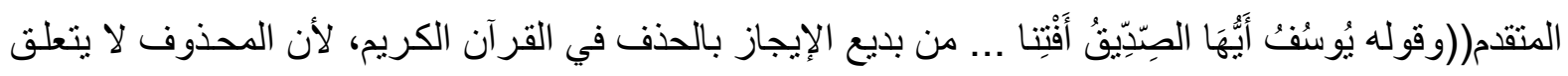

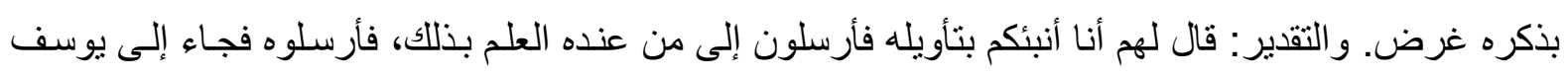


في السجن فقال له: يا يوسف يا أيها الصديق. والصديق: هو الإنسـان الذي صسار الصدق دأبه وشيمته في كل

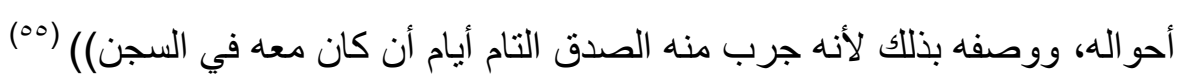
ويأتي الحذف في باب الإرشاد الممزوج بالرحمة الإلهية, ليطرح دلالات متنو عة, مضمرة, نرشد الناس إلى

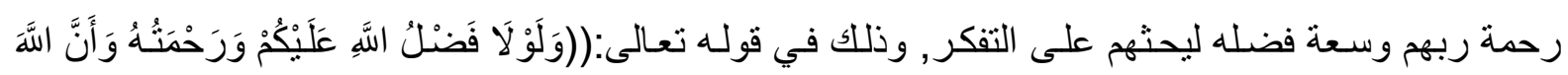

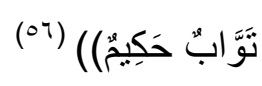

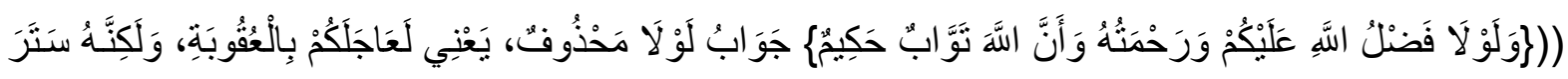

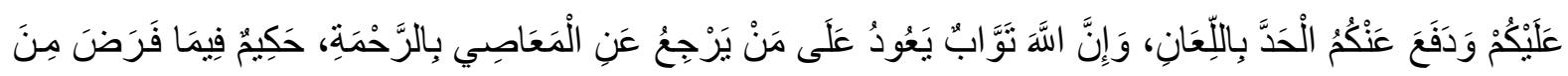

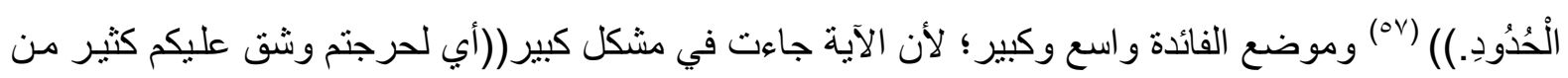

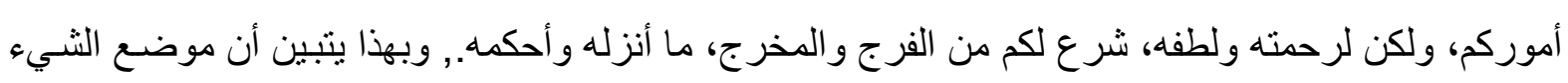

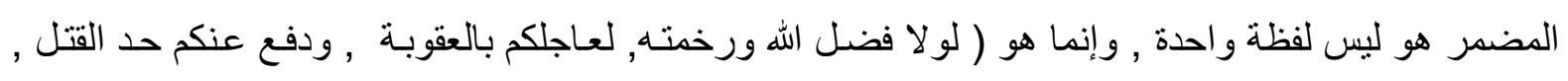
ودفع الثلك, و أسس لكم الفرج , و المخرج...). وفي ذلك اتساع دلالي جلبه الطـابع الإرشـادي الذي قدمـه الطرح القرآني. قال ابن كثير : هذه الآية الكريمة فيها فرج للأزو اج وزيادة مخرج، إذا قذف أحدهم زوجته وتعسر عليه

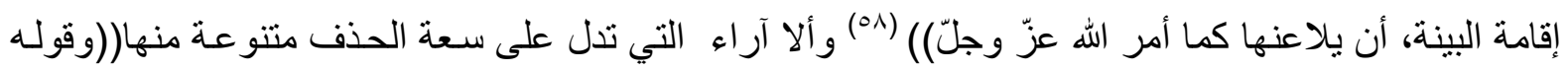

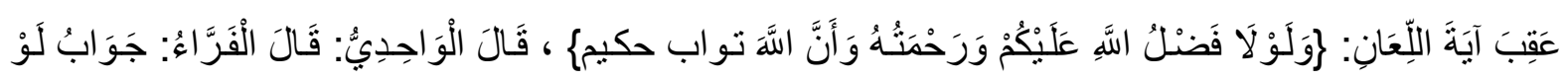

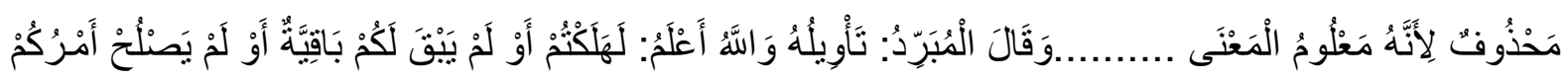

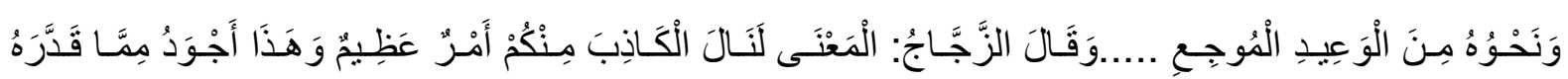

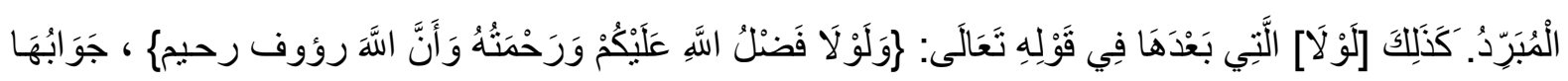

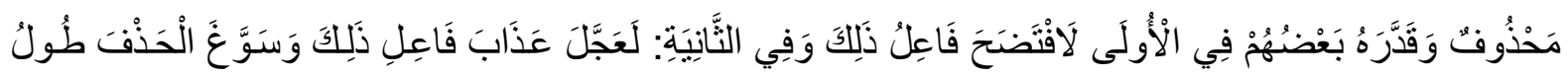

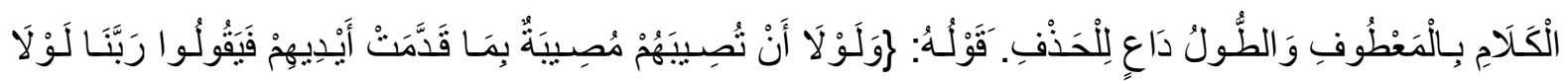

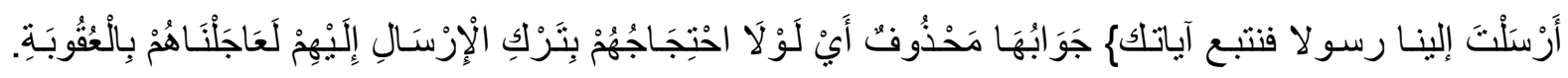

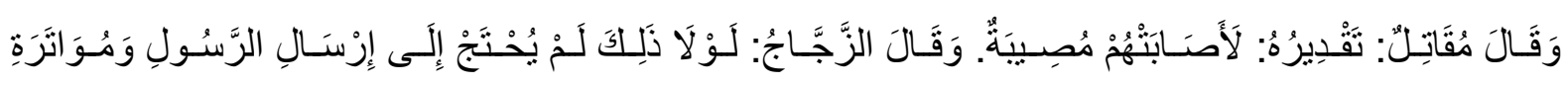

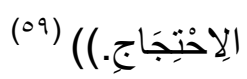

ومن الآيات التي جاءت تحمل بنية الحذف , و التي أعطت معنى الاتسـاع الدلالي , تلك التي أتت مشـابهة للآيـة السابقة في تبيان رحمة الله سبحانه وتعالى , بيد أنها قد نزلت في اليهود لتبين رحمـة الله وفضله عليهم , ذاك الك الذين قابلوه بالصد و الإنكار, فتخرج في طابع تذكيري إرشـادي, وفي الوقت ذلك لا يخفى مـا فيـه من مسحة

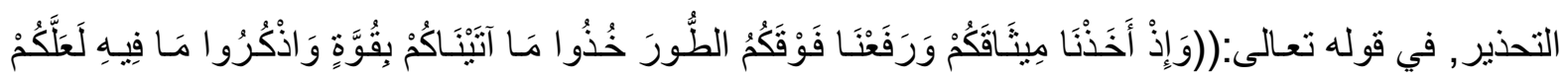

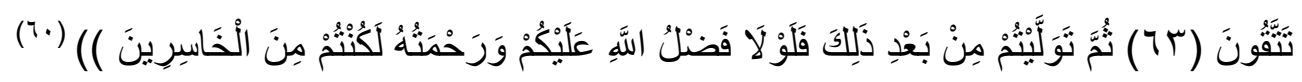
فلفظة الخاسرين قد حملت ور ائها دلالات إرشادية تقوم على التنبيه للمحذوف المطروح؛ لأنه كثير وفيه

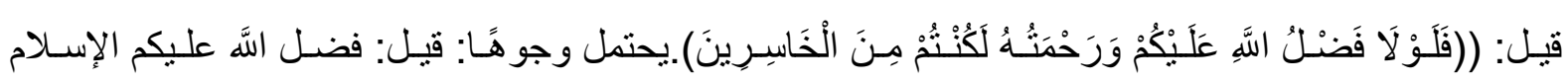

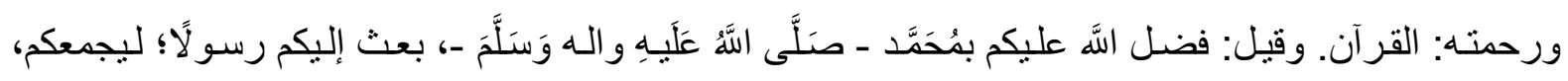


ويؤلف بينكم، ويدعوكم إلى دين اللَّ الحق، بعد ما كنتم في فترة من الرسل، وانقطاع من الذِّين والعمل. ويحتمل:

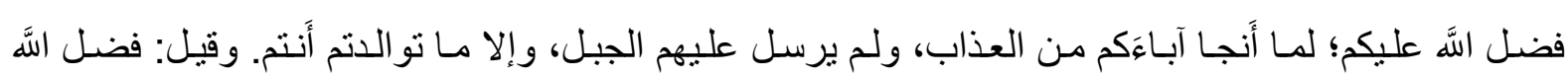
عليكم؛ لما أَعطاهم التور اة، ووفقهم على قبولها، و إلا كنتم من الخاسرين. وبعضه قريب من بعض)( (ال") ويقول

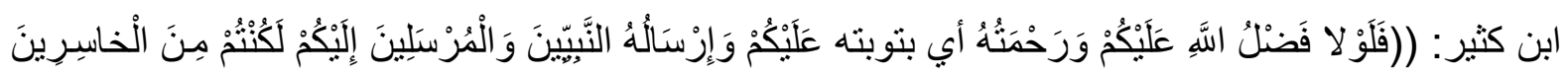

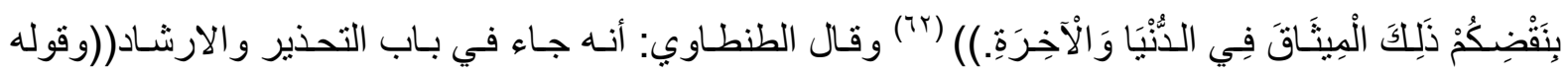

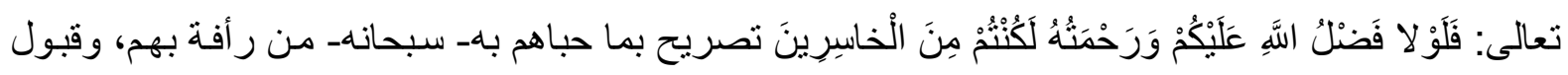
لتوبتهم، و عفو عن خطيئاتهم، فكأنهـ سبحانه- يقول لهم: إنكم بإعر اضكم عن طاعتي، ونقضكم لعهدي، و إهمالكم العمل بكتابي، و عدم تأثركم بآياتي ونذرى، قد استحققتم غضبى وعذابي، ولكن حال دون حلولهما بكم. فضلي

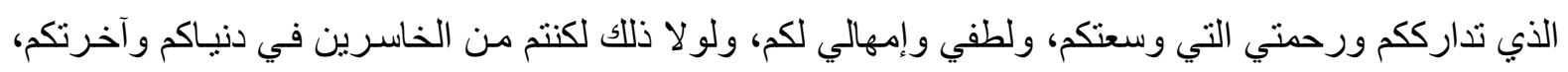

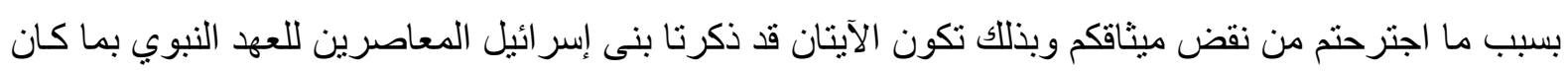
من أسلافهم من جحود النعمة، ونقض للعهد، وفي هذا التذكير تحذير لهم من السير على طريقتهم، ودعوة لهم

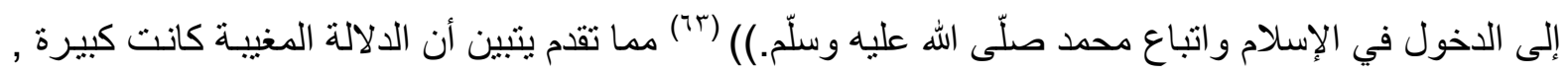
فلذا جاء الحذف ليفتح الباب على الدلالة المتوقعة التي تقابل رحمة الله الواسعة سبحانه وتعالى. ومن الآيات التي تدعو للإرشاد المبين للرحمة الإلهية تلك التي تظهر فيها كلمة لو لا, فيختفي ورائها الحذف المنسع, الذي يبين صعوبة الإحاطة بالرحمة الربانية , ومنه قوله تعالى :

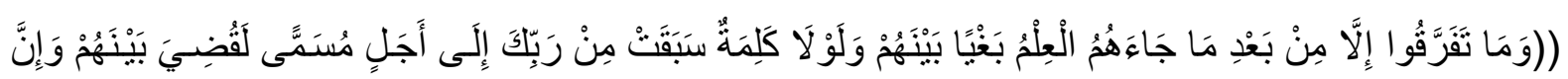

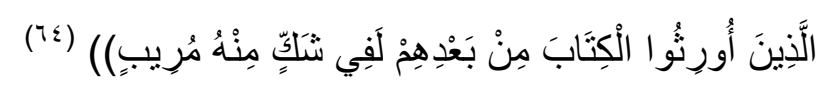
فالحذف ظاهر في الآية المباركة, يقول : الزجاج التقدير (( لَجُوزُوا بأعمالهم، والكلمة هي تأجيله السـاعة،

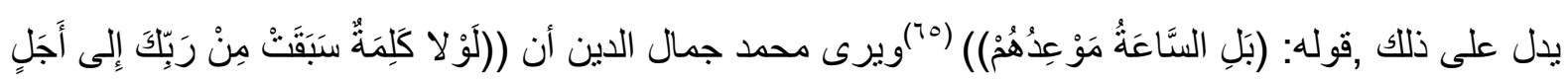

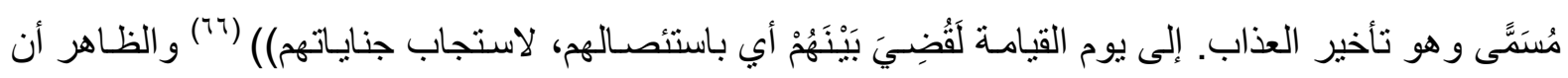

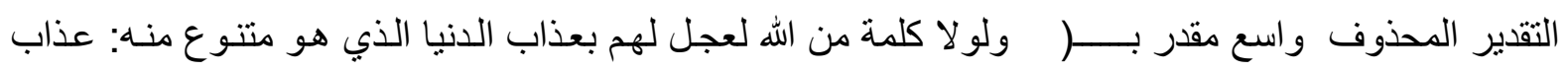

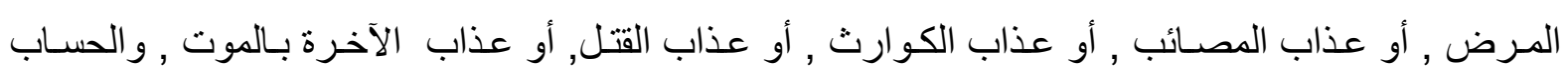

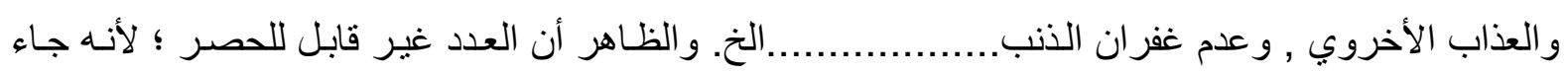
في رحمة الله سبحانه وتعالى., ليتضح فضل الله سبحانه على الناس. ويدخل الحذف للاتساع في باب الإرشاد و التوجيه الداعي للإيمان بـاله ـ جل ذكره ــ الذي يتضمن أشنياء كثيرة تقف مقابلا لإحداث شرط الإيمان والتي لا يمكن للذكر أن يستو عبها, لطولها , وكثرتها , وربمـا لتجددها

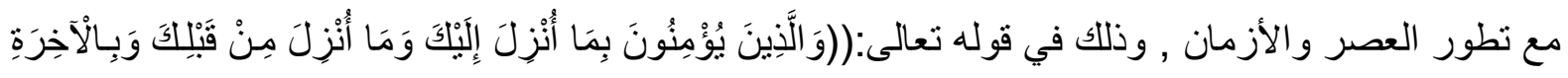

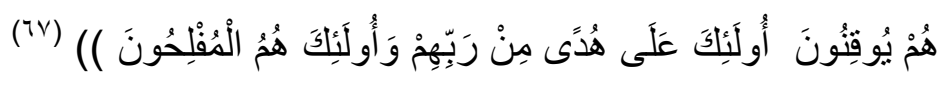
فالنص القرآني موجه لإرشاد اليهود لطبيعة الايمـان وتحذيرهم من الوقوع في الزلل و العنـاد فـــ(الذين يُوِْْنُونَ هم مؤمنو أهل الكتاب كعبد الله بن سلام وأضرابه من الذين آمنوا بكل وحي أنزل من عند الله وأيقنوا 
بالآخرة إيقاناً زال معه ما كانوا عليه أنـه لا يـخل الجنـة إلا من كان هوداً أو نصسارى وأن النـار لن تمسهم إلا أياماً معدودات ثم إن عطفتهم على الذين يؤمنون بالغيب دخلو ا في جملة المتقين و إن عطفتهم على المتقين لم

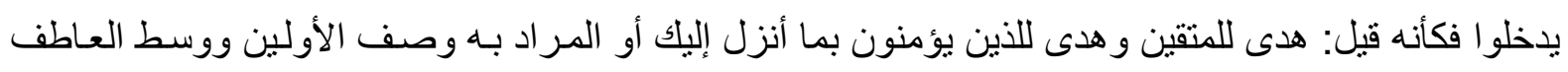
كما يوسط بين الصفات في قولك هو الثجاع و الجواد وقوله ... إلى الملك القرم وابن الهمام ... وليث الكتيبة في

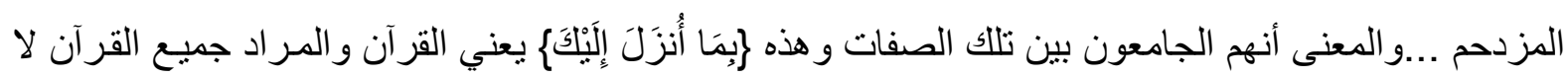

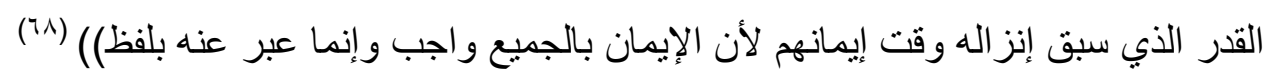

فالنص القر آني المبين لطبيعة وماهية الايمان المطلوب هنـا يدل على شمولية كبيرة لا تحصر فالإيمان هنا كما يبينه حسن أيوب قائلا : ((سأل جبريل النبي (صلى الله عليه و اله وسلم) عدة أسئلة تعليميـة وكان منها قوله: فأخبرني عن الإيمان؟ فال:" أن تؤمن باله، وملائكته، وكتبه، ورسله، واليوم الآخر، وتؤمن بالقدر خيره

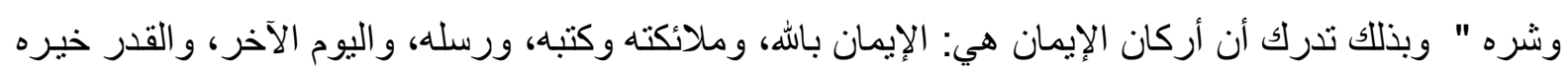

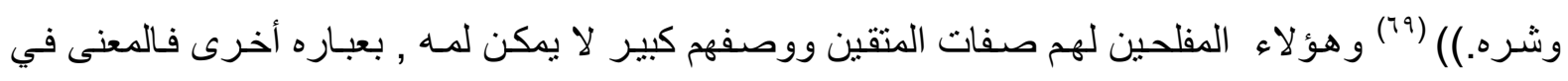
الحقيقة أوسع من ذلك فالإيمان المطلوب فيه النصح في اتباعه هو: ايمـان المتقين و المؤمنين بالعذاب والجنـة , و المؤمنين بما أنزل من نرك المحرمات و إقامة الصلوات و أركان الدين كلها والمؤمنين بالغيب والمصدقين بيوم

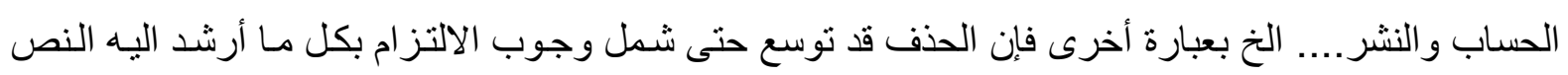
القر آني وترك كل ما نهى عنه و الثيء حاصل مع النبي وحديثه الثريف . . وحذف جملة أو أكثر من جملة ورد كثير ا في النص القرآني في باب القص, وكثير منه أريد به الإرشـاد أو التوجيه، وقد جاء للتركيز على الأهم, ومن أمثلته قوله تعسالى في حكايـة موسى عليه الستّلام مـع أب ابنتي

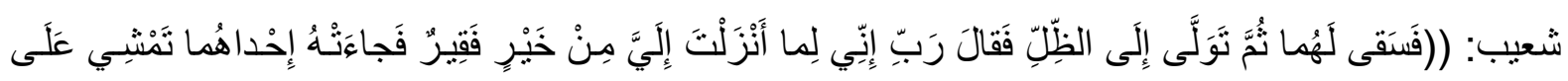

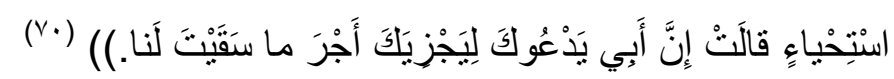

فـالنص المغيب هـو نص قصصسي فيه سـرد, كثير ولكن جـاء الحذف مركز ا على الأهـم, والبـاكورة و المحصلة النهائية ((فالمحذوف هنا جمل عدة، ونظم الكلام من غير حذف أن يقال: فذهبتا إلى أبيهما وقصتا

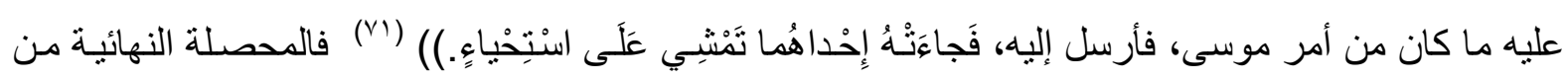

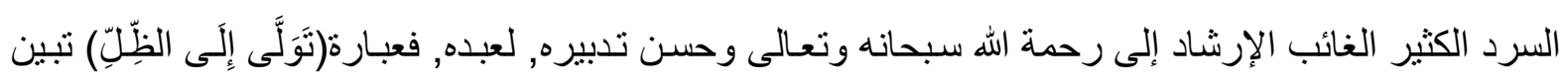

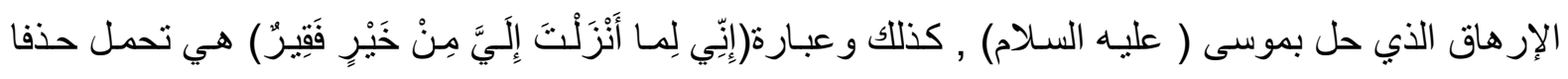
منسعا, فيمكن تقديره( فقير لرد جمائلك وسترك لي وحفظك وكمال عنايتلك...) ولذا يسطع الأهم وهو فرج الله

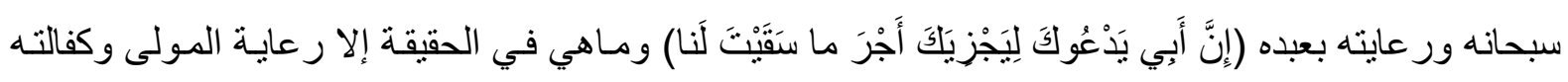
لعبده بالأمان و العمل و الطعام والأسرة.. و الله العالم. بعلئ.

ومن أمثلة الإيجاز في القصص القر آني بحذف أكثر من جملة أيضا قوله تعالى في قصـة سليمان وقصـة

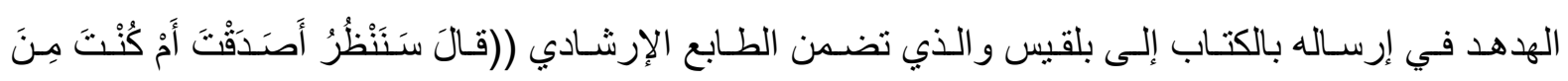




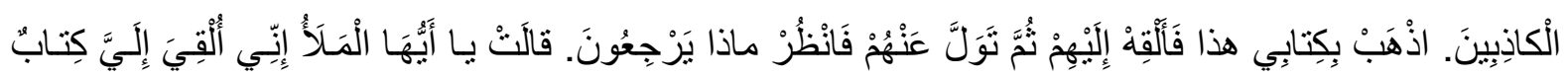

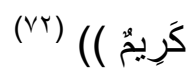

فالآيـة المباركة جاءت في بـاب الإرشـاد و التوجيـه الممزوج بالتحذير, فالتوجيـه والإرشـاد, نقلته العبـارة الموجهة إلى الهدهد من قبـل النبي سـليمان عليه السـلام :( اذهب بكتابي هذا...فانظر مـاذا يفعلون) فالتوجيـه يتضمن إلقاء الكتاب ورؤية ماذا يكون من أمر هم, أمسا التحذير فقد تضمنه مضمون الكتاب, ويظهر أن النص هـ القصصي القر آني قد تضمن حذف أكثر من جملة, ليخلق حالة من الاتسـاع والتخيل للمشهدية المتصورة بعد

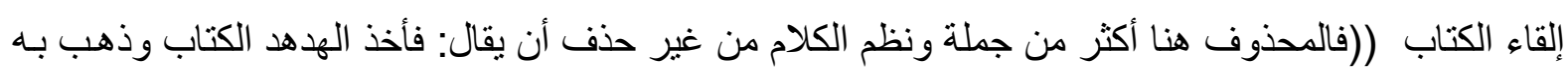

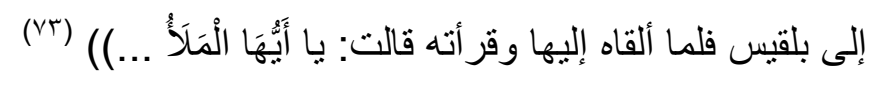
ومن أمثلة حذف الجملة التي تدخل في باب الإرشاد التوجيه والتي تحمل معنى الاتساع في الدلالة الغائبة،

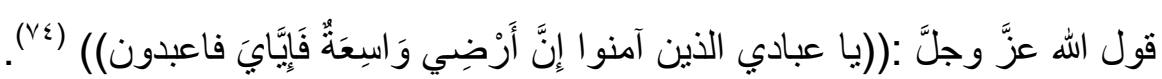
فالنص الإرشادي القر آني يأتي بيسر وسهولة, ليتو اشتج مع مضمون النص الإرشـادي, فيتقدم النداء للتنبيه, وتدخل عبارة ( عبادي) للتقريب, ثم يدخل الحذف الجملي بعد ( إن أرضي و اسعة) ((أي: فـإنْ لم بتأَتَّ لكُمْ

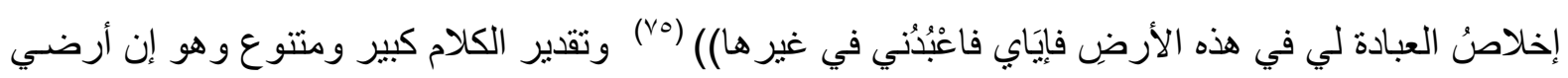

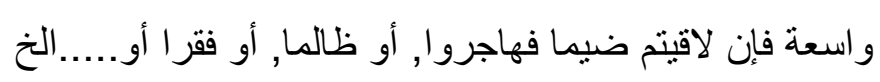
ومن الآيات التي جاءت في باب القصص القرآني, والتي تحمل معنى الإرشـاد و التوجيه وفيها حذف أكثر

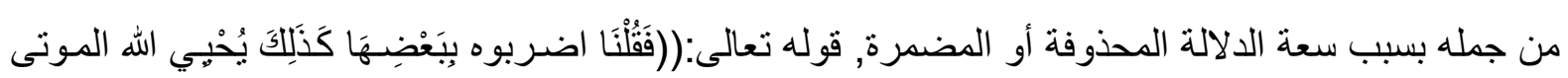

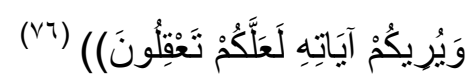

فالقصـة داخلـة في بـاب الإرشـاد و التوجيـه, ويظهر الإضــار الذي يخفي وراءه الاتسـاع فعبـارة ( فقلنـا اضـربوه) أخفت ور ائهـا حذف جملي مقدر بـــ((أي: فقلنـا اضـربوا القتيـل ببعض البقرة المذبوحسة، فضـربوه

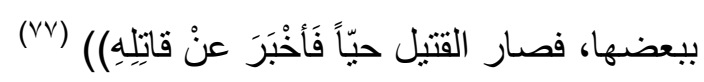
ومن باب الارشاد والتوجيه الذي تضمن, مخاطبة اليهود الذين ظلاوا وغاب عنهم الرشـد, فظلموا أنفسهم,

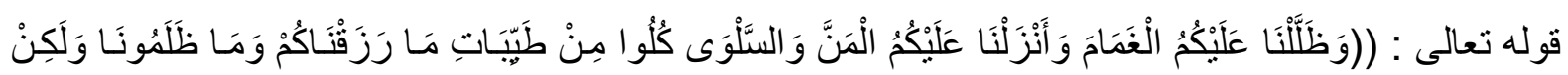

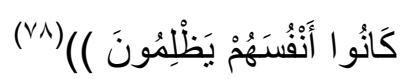

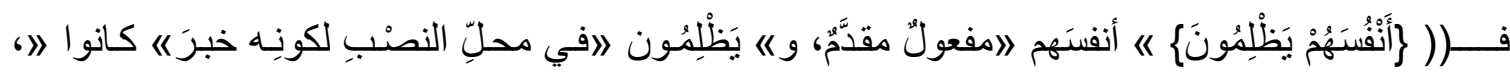

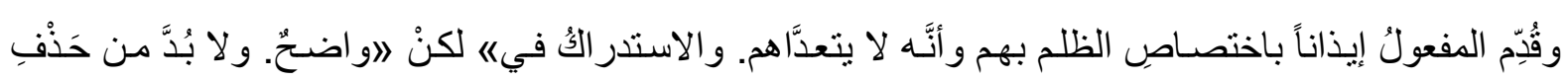

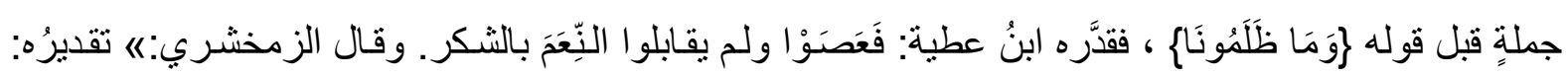

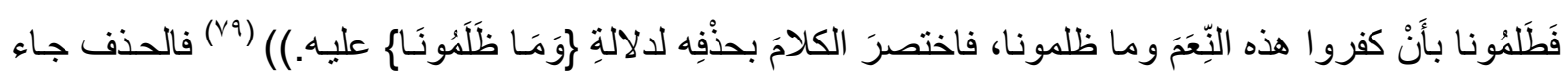

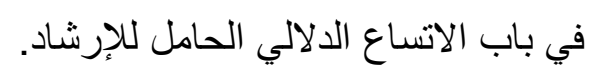


ومن الحذف الدال على التوسع من خـلال الإرشـاد الممزوج بـالتقريع, هو مخاطبة موسى عليه السـلام

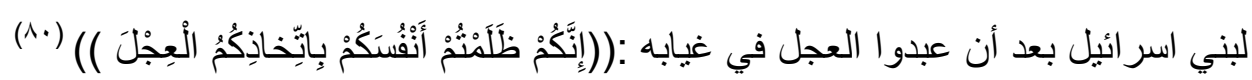

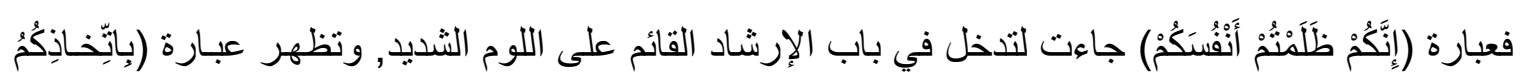

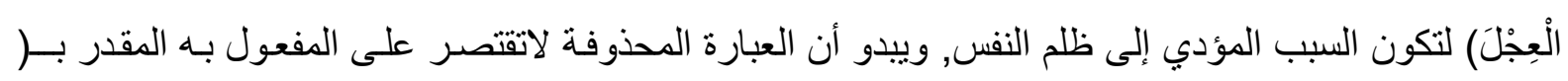
باتخاذكم عبادة العجل) بل تتجاوزه إلى حذف جملي, بينه صساحب التفسير المحيط بقوله أن فيه:((حَذْفَ جُمْلَةٍ

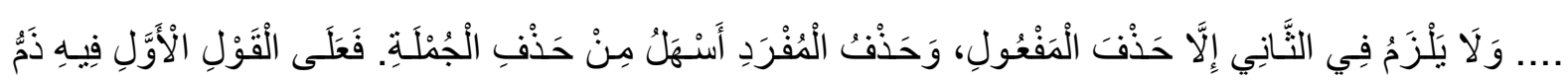

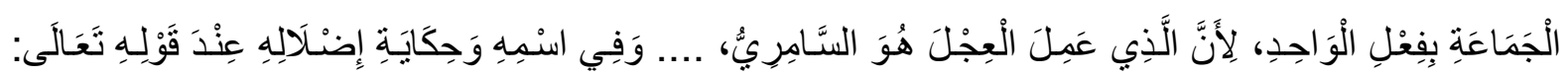

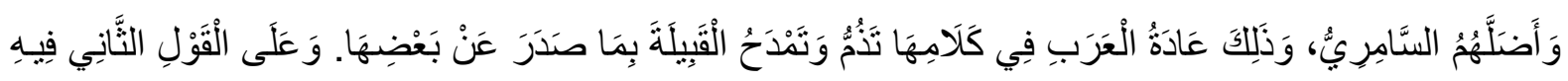

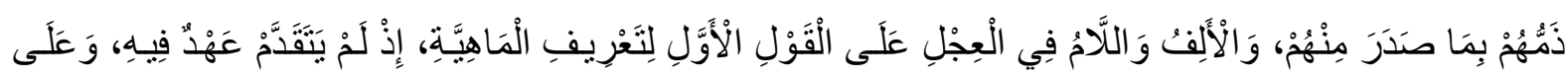

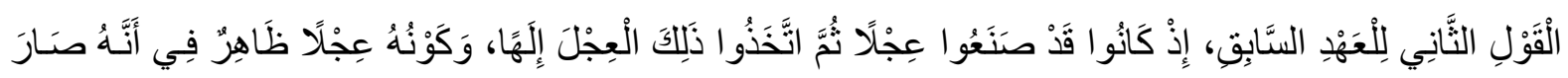

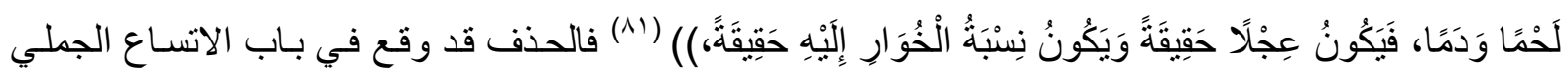
الذي لا يستو عبه لفظ واحــ. فالعبـارة يمكن أن تقدر( إنكم قد ظلمتم أنفسكم حين غيبتم العقل وتركتم الله , وصدقتم السامري و أعطيتموه عقولكم و أنفسكم وذهبكم فصنع لكم عجلا لـه خوار فعدتموه...) و هذا الحذف فيه اتساع, ويظهر - والله أعلى - أن السبب القابع وراء ذلك هو التركيز على الأهم, وترك مـاسوى ذلك ؛ لأته ذكره مؤلم.

ومن أمثلة الحذف الجملي الداخل في باب الإرشـاد و التوجيهه والذي يدخل في بـاب الاتسـاع في المعنى

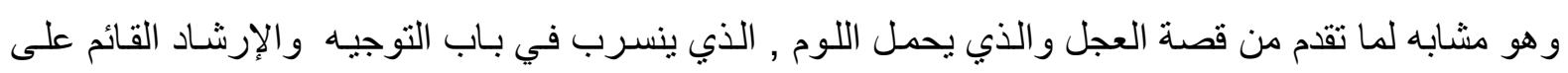

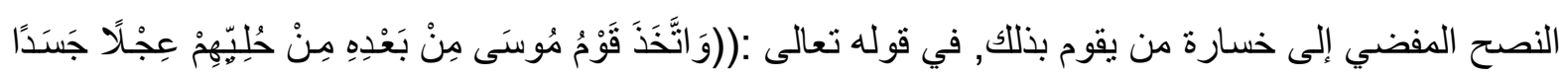

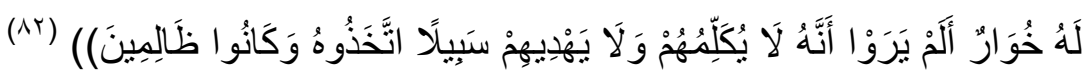
فالاتسـاع الدلالي القرآني داخل في بـاب حذف الجملـة التي تخفي ورائهـا التوسـع في المعنى , يقول

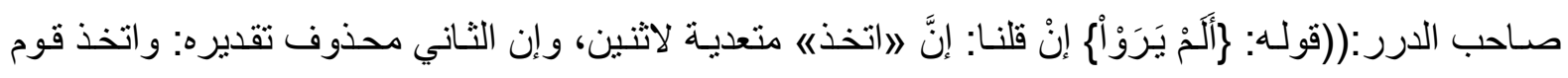
موسى من بعده عجلاً جسداً إلهاً فلا حاجة حينئذ إلى ادِّعاء حذف جملـة يتوجَّهـه عليها هذا الإنكارُ، و إن قلنـا إنها

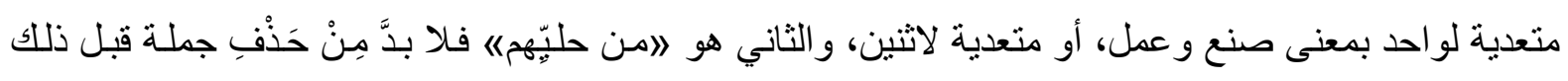

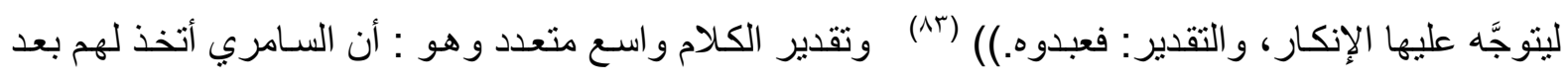
غياب موسى عجلا ليس حقيقيا وجمع حليهح, وكان ذللك من نقص عقولهم وقلة ايمانهم....الخ بعبارة أخرى فئان النص فيه إرشاد وتوجيه إلى قلـة عقولهم تلك العقول التي عبدت مـالا ينفع و لا يضـر, من دون الله تعـالى مـع وجود الدلائل, وذلك الأمر يؤدي إلى الاعتبار والتفكر وعاقبة الخسران لمن ضيع دينه بمخالفة العقل و المنطق و الحجج و البر اهين الثابتة.

وقد يأتي الحذف القرآني داخلا في باب التوسع الدلالي فيما إذا كان الطرف المقابل لدية قدرة على إطاعة الأمر الرباني بكل حذافيره وبأدق تفاصيله فيكون الذكر غير قادر على الإحاطة بذلك الطرح, كما في بـاب 
إقرار الأنبياء لله سبحانه وتعالى وسر عة الاستجابة وتتو عها, و لا يخفى ما في النص من جانب إرشادي فالأنبياء

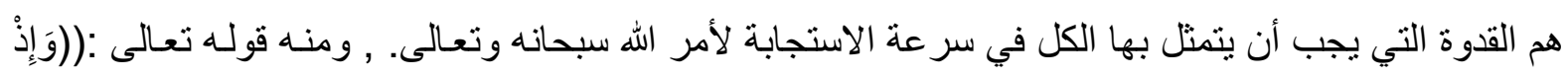

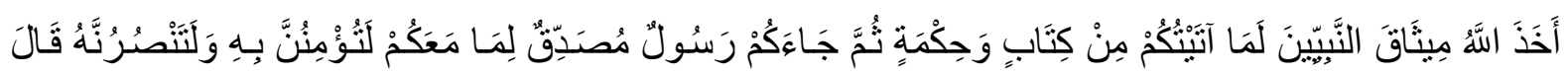

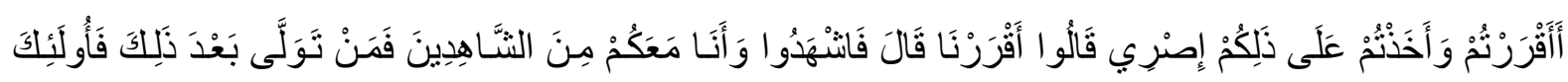

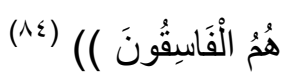

ففي النص المتقدم حوارية بين الله سبحانه وتعالى وبين النبيين صلوات ربي عليهم أجمعين, , ويأتي الاستفهام من الله ـ سبحانه وتعـالى - ( أققررنم) موجها للأنبياء طالبـا للجواب المنسار ع لقصر الأداة ولخاصية

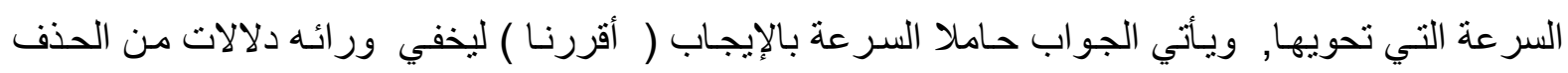

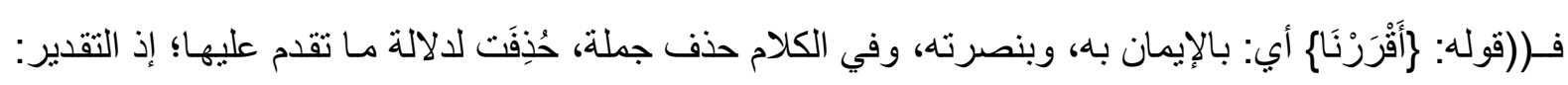

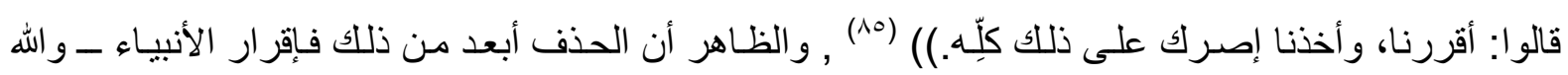
أعلم ـ قد جاء بكل ما أنزل الله من الكتب , و الأنبياء , وبكل تعاليمه , وبهديه , وبجهاده , وبحلاله, وحرامـه ,

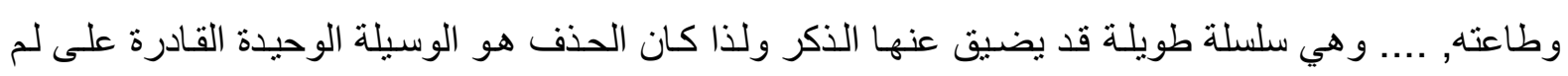

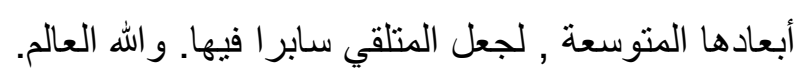
وقد يأتي الحذف في بـاب الإرشـاد الحامل للوم والتحذير , ومنـه قول الله سبحانه وتعـالى , حين انهزم المسلمون لما سمعو ا بخبر قتل النبي , كذبا فجاء اللوم , الحامل للإرشاد ليتضمن العبرة التي جاء الحذف متخلالا مفاصلها ليلم الحدود الإرشادية عن طريق وسيلة التذكير , وربط النبي محمد (صلى الله عليه واله وسلم) بمن قبله من الأنبياء السابقين الذين تعرضو اللأذى والقتل , مع صبر أقوامهم ليتم النصح و الإرشساد , وذلك في قولـه

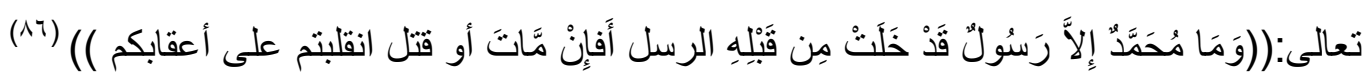

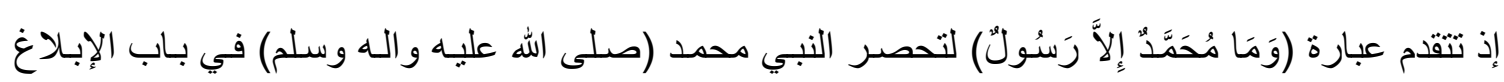
للارسالة, وتهون من موته أو قتلكه أمام وجود الله سبحانه وتعـالى وبقاء, ويدخل الحذف في مفاصلها فـــ((قوله:

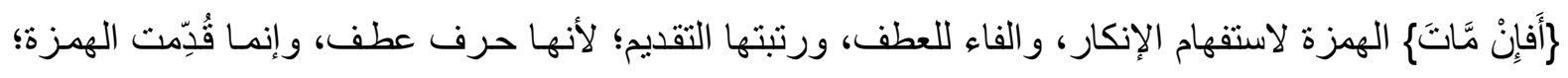
لأن لها صندر الكلام، وقد تقدم تحقيقه وأن الزمخشري يقدِّر بينهما فعلاً محذوفاً تعطف الفاء عليه مـا بعدها. قال

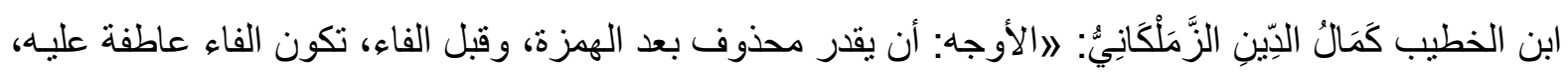

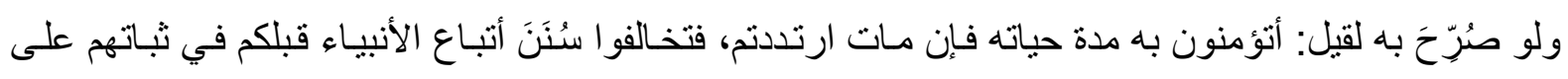

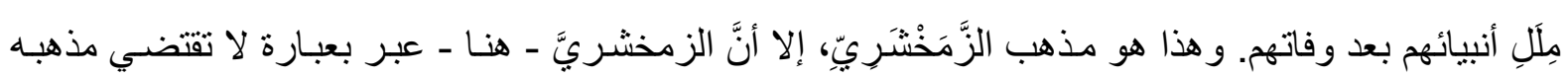

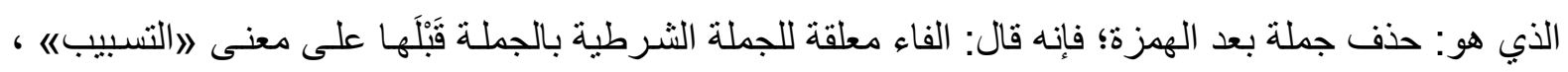

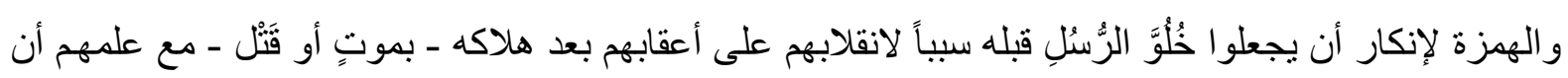

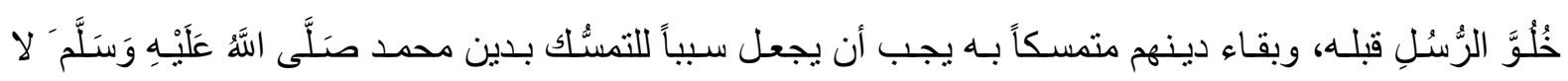

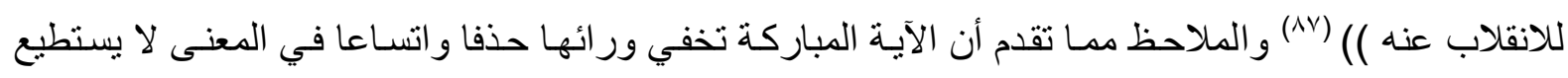
الذكر لمه وحصره , و إنما عمل الحذف على استيعاب مفاصله. 
ومن بـاب الحذف الداخل في بـاب الإرشـاد والتوجيه, الذي يصل إلى التحدي, ويبقى في إطسار تحريك العقول إلى الدليل, قوله تعالى مخاطبا المكذبين للقر آن الكريم زاعمين أنه من صنع النبـي الأكرم (صلى الله

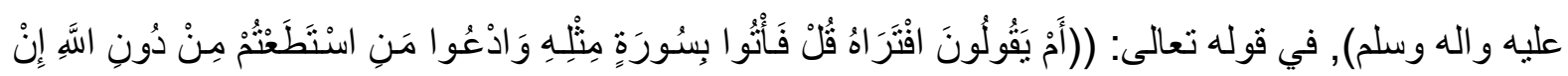

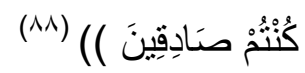
فعبارة (أَمْ يَقُولُونَ) فيها الإنكار المتمثل بالهمزة, التي تخفي ورائها الحذف القائم على الاتسـاع في المعنى

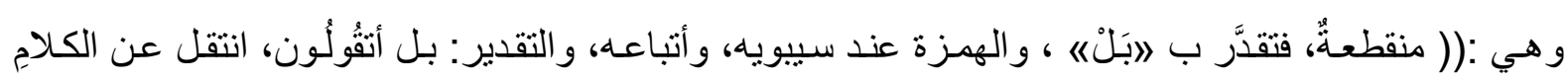

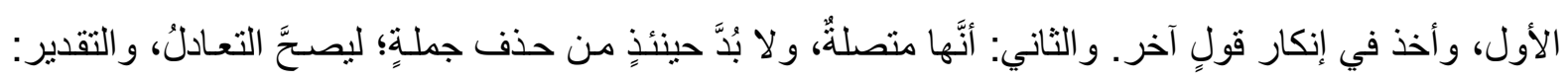
أيقرون به، أم يقولون افتر اهُ، وقال بعضهم: 》أمُه هذه بمنزلة الهمزة فقط، و عبَّر بعضهم عن ذللك، فقال: الالميحُ

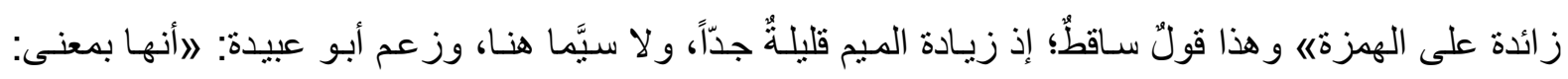

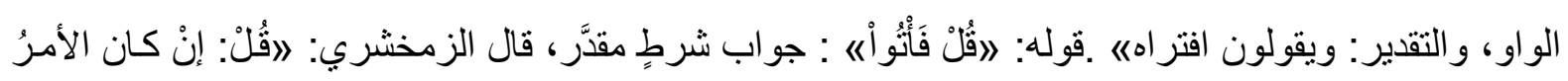

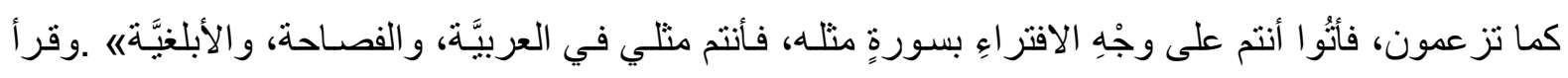

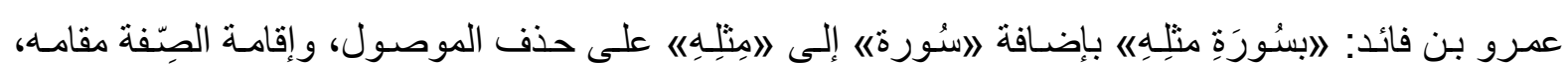
والتقدير: بسورة كتاب مثله، أو بسُورة كلام مثله، ويجُوز أن يكون التقديرُ: فأتُو البسورةٍ بشر مثله، فالضَّمير

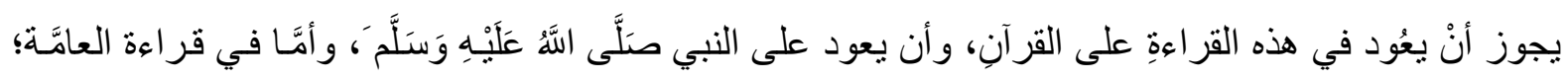
فالضمير للقرآن فقط فإن قيل: لِحَ قال في البقرة:

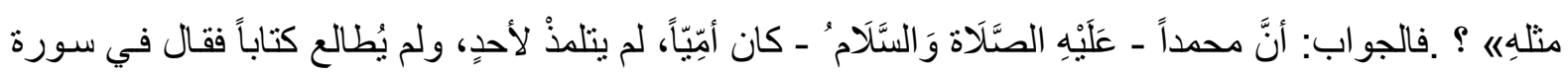
البقرة: امِن مثلهه أي: فلَيَّاتِ إنسان يساوي محمَّدا (صلى الله عليه واله وسلم) في هذه الصِّفات، و عدم الاشتعال

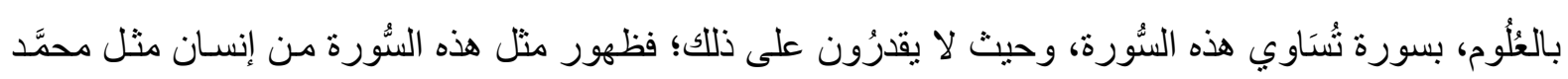

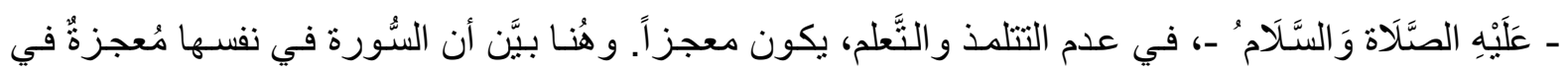

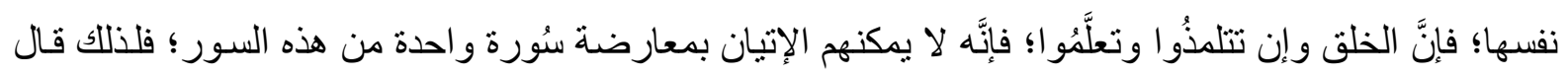

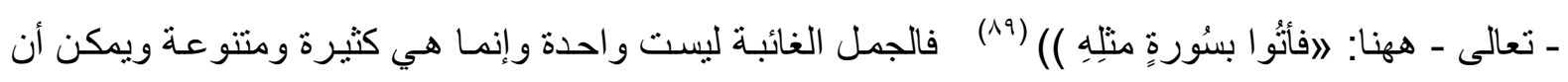
تكون: ((: أيقرون بحقيقة القرآن، أم يقولون: افتراه؛ أي: بل يقول كفار مكة: اختلق محمَّد، - صلى الله عليه وسلم -، القرآن من تلقاء نفسه؛ أي: ما كان ينبغي أن تقولوا: إن محمدًا، - صلى الله عليه وسلم -، افتراه من عند

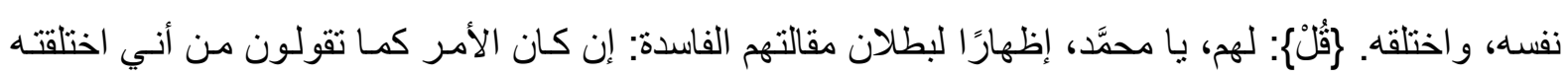

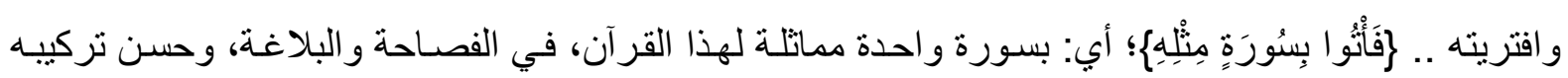

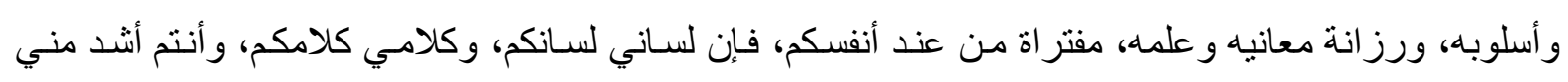

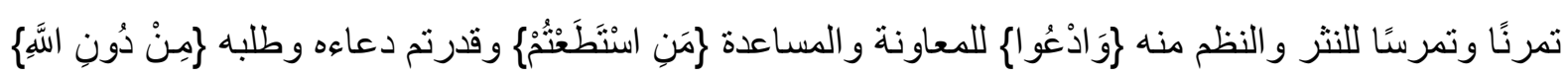

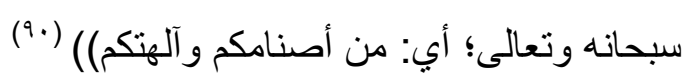
وبعد المرور بهذا البحث الذي أدخلنا في بركات القرآن الكريم الذي وقفت أمامـه العقول حيرى لبلاغته , وبيانه , و إعجازه اللغوي يحاول الباحث أن يضع أهم النتائج الني توصل إلبها البحث: 
اــ القر آن الكريم في مجملـه داخل في بـاب الإرشـاد والتوجيهه , فالقصص القر آني داخل في ذلك , وكذلك التحذير , وبل وحتى آيات العذاب الأخروي , تقوم على التهويل المغلف بالإرشاد و التحذير. rـ الحذف كما شاع في النحو وفي البلاغة العربية قائم على حذف حرف أو كلمة أو جملة أو جمل , وظهر من خلال البحث المقدم أن المسألة تتجاوز ذلك , فالحذف و إن كان في كلمة واحدة فإن إضمار ها يخفي جمـا عدة , ولو كان الأمر عائدة على الكلمة لربما كان ذكر ها لا يشكل أثرا كبيرا بقدر الجمل المحذوفة. זـ الحذف يقوم على الإيجاز , بيد إن النص القر آني لم يكن الهدف فيه هو الإيجاز بقدر مـا كان الهدف وراء

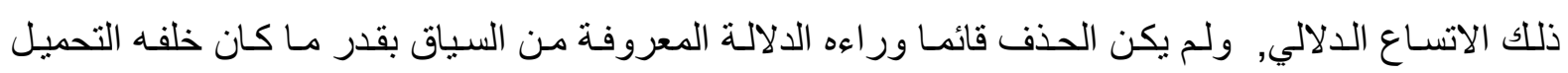
الدلالي لمعاني متنو عة قد لا يمكن لمها من خلال لفظة واحدة ذكرت لحن. عـ القر آن الكريم هو كتاب سماوي يناسب الأزمـان كلها والعصور و الأمزجـة و التقافـات المنوعـة , ولهذا جـاء الحذف مشكلا الاتساع الدلالي القادر على استيعاب الدلالات المتطورة في الأزمان كلها. ○ـ قد يأتي الحذف ليشكل الاتساع الدلالي الذي لا يقوم إلا بالحذف فيما لو جاء في بـاب العد للأشياء التي لا يمكن إحصائها , كما تبين في البحث المقدم مثل إحصاء نعم الله سبحانه وتعالى على المؤمنين, أو على الأنبياء و المرسلين.

7ـ قد يأتي الاتسـاع الدلالي في بـاب الصور القرآنيـة التي تخفي مشـاهد وراء لفظـة مضمرة, فتظهر الصور المتسعة خلف اللفظة المضمرة, لتكون معها قادرة على استيعاب التكثيف الصوري الغائب , كما وصف مشـاهد العذاب الأخروي.

\section{فهرس الهواهش}

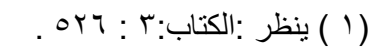

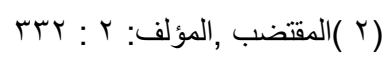

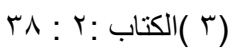

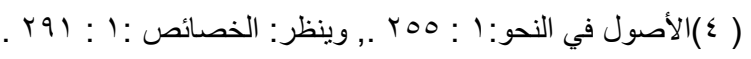

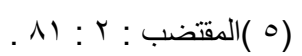

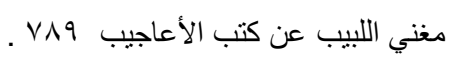

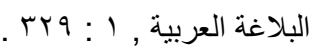

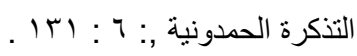

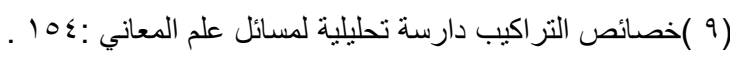

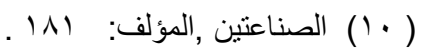

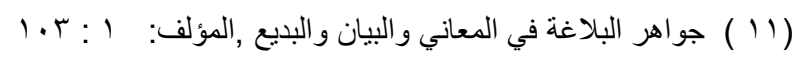

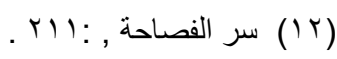

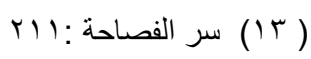

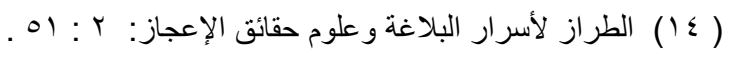

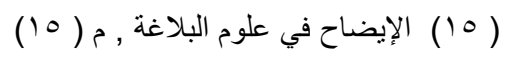

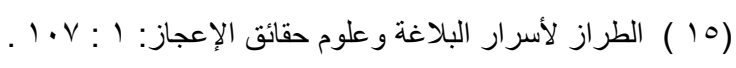




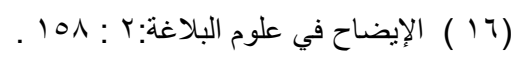

$$
\begin{aligned}
& \text { ( البقرة/ ( IV) } \\
& \text { ( البقرة/ (1) }
\end{aligned}
$$

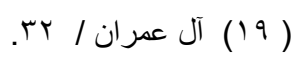

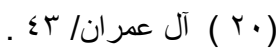

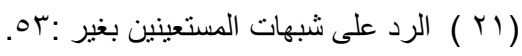

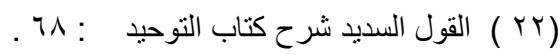

$$
\begin{aligned}
& \text {. IV }
\end{aligned}
$$

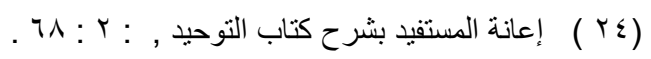

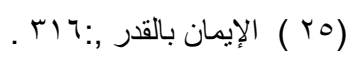

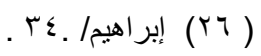

$$
\begin{aligned}
& \text { (YV) } \\
& \text { rVo : تفسير الماوردي = النكت والعيون: TA ) }
\end{aligned}
$$

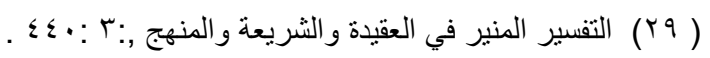

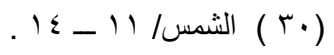

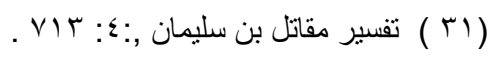

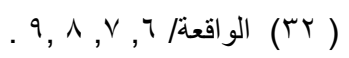

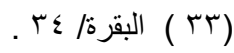

$$
\begin{aligned}
& \text {. } 0: \text { : }
\end{aligned}
$$

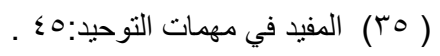

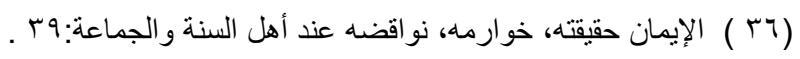

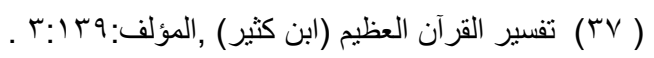

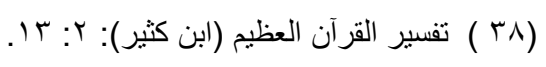

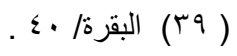

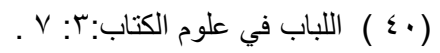

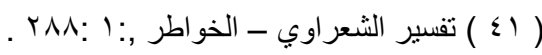

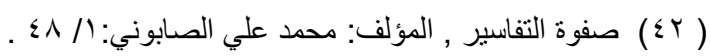

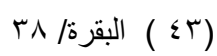

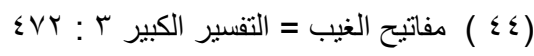

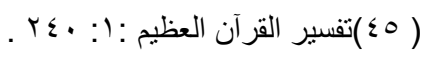

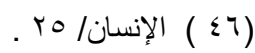

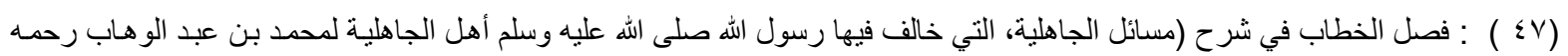

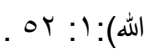

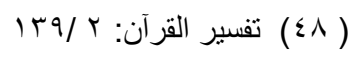

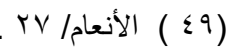

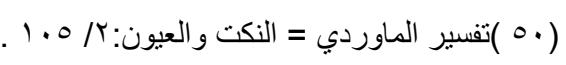

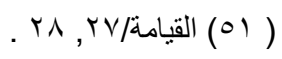$$
\text { ) ( }
$$

( (

$$
\text { ( }
$$




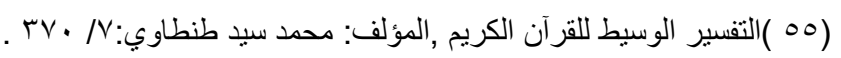

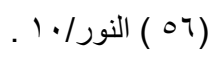

IV/ T T (OV)

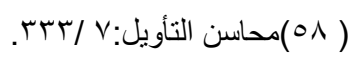

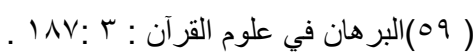

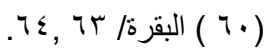

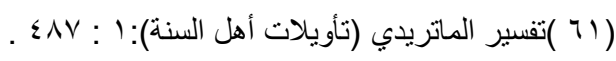

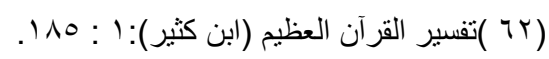

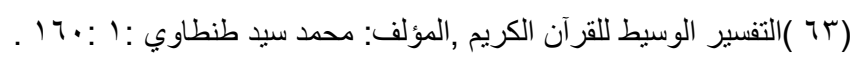

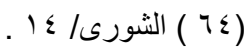

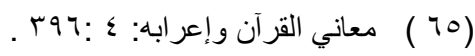

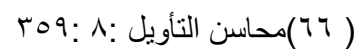

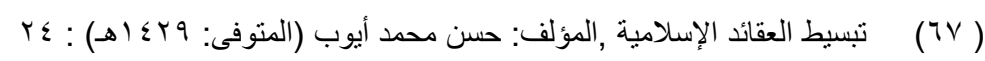

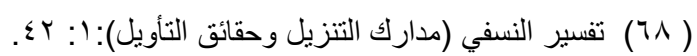

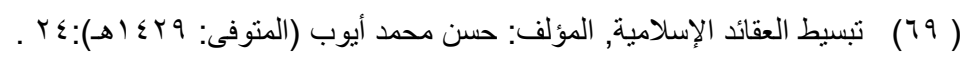
ro/ ( V. )

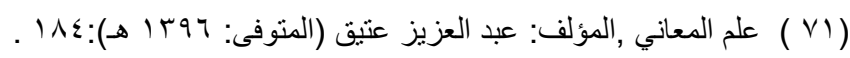
.

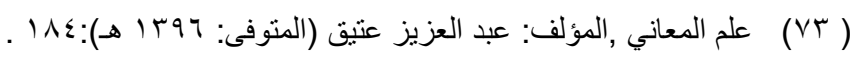
r $9 /$ ( V العنكبو (V)

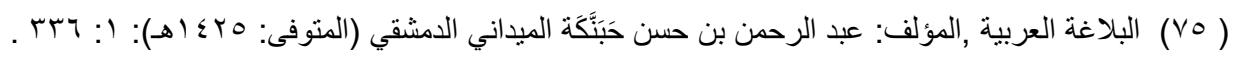
. T البقرة (VT)

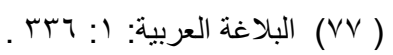
البقرة/ ( V^)

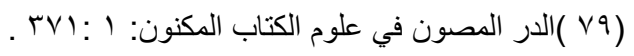

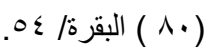

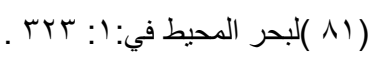

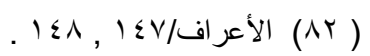

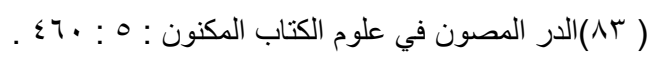

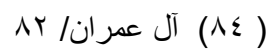

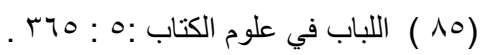

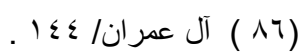

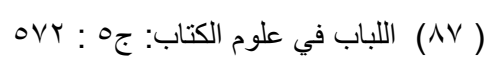

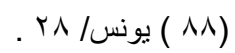

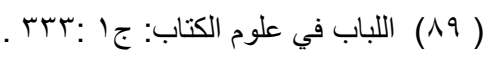

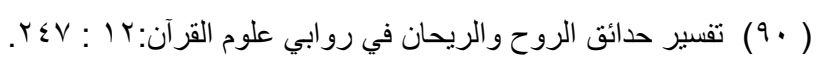

سالأصول في النحو ,المؤلف: أبو بكر محمد بن السري بن سهل النحوي المعروف بابن السراج (المتوفى: 7 اسهـ) ,المحقق: عبد الحسين الفتلي

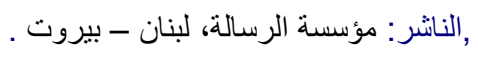




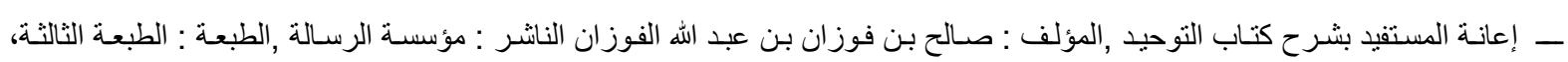
. $r$ r.

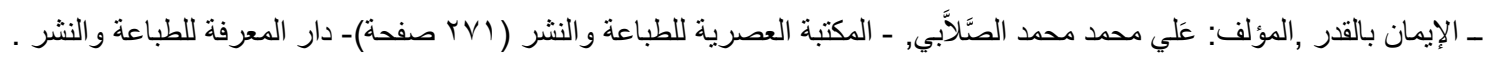
ـ الإيمان حقيقته، خوارمه، نو اقضه عند أهل السنة والجماعة ,المؤلف: عبد الله بن عبد الحميد الأثري ,مراجعة وتقديم: فضيلة الثيخ الدكتور

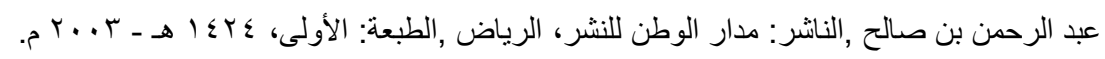

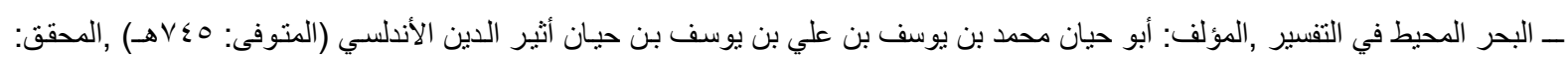

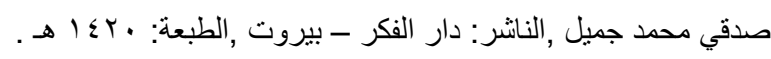

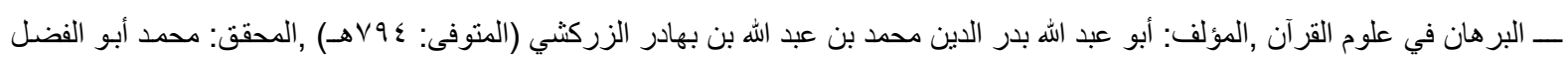

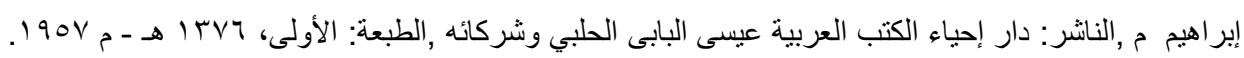

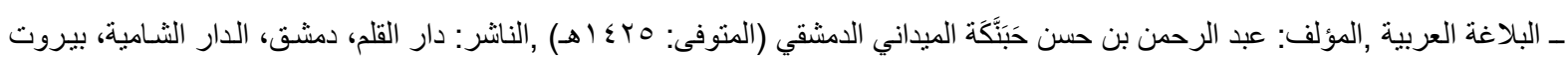

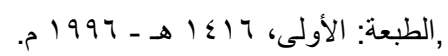
ـ تفسير النسفي (مدارك التنزيل وحقائق التأويل) المؤلف: أبو البركات عبد الله بن أحمد بن محمود حافظ الدين النسفي (المتوفى: الهــ),حققه

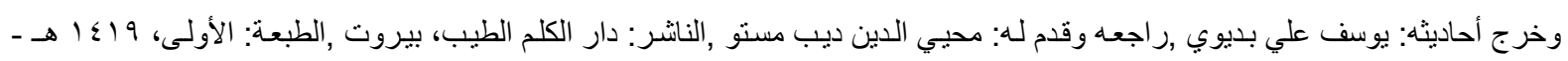
م. 1991

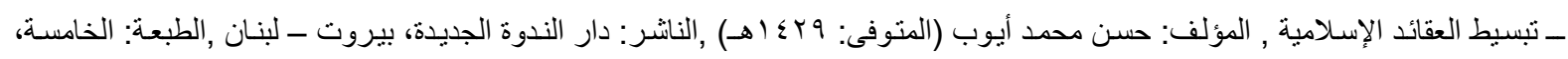

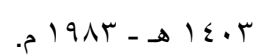
ــ التذكرة الحمدونية , المؤلف: محمد بن الحسن بن محمد بن علي بن حمدون، أبو المعالي، بهاء الدين البغدادي (المنوفى: ب7هــ) ,الناشر : دار

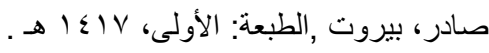
ـ تفسير القرآن ,المؤلف: أبو المظفر، منصور بن محمد بن عبد الجبار ابن أحمد المروزى السمعاني التميمي الحنفي ثم الثـافعي (المتوفى:

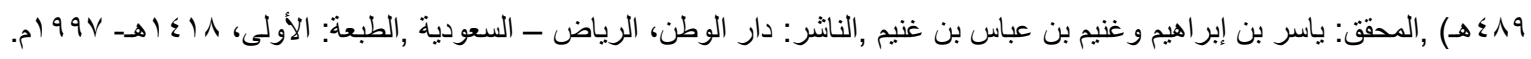

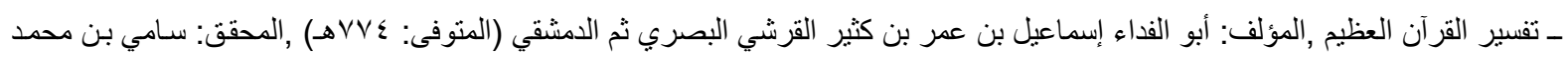

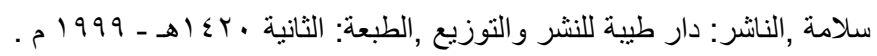

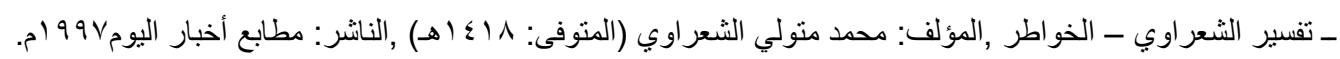

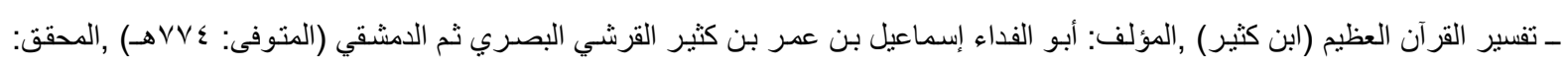

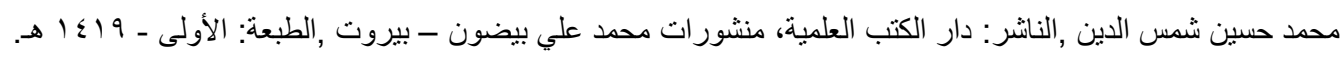

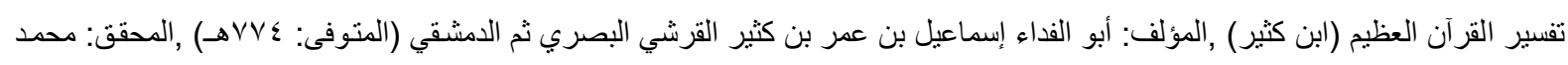

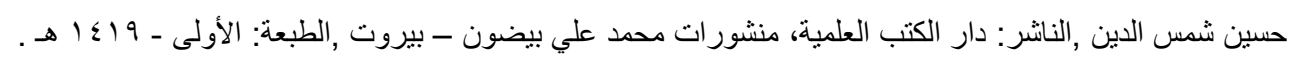
ـ تفسير الماوردي = النكت والعيون ,المؤلف: أبو الحسن علي بن محمد بن محمد بن حبيب البصري البغدادي، الثـهير بالماوردي (المتوفى: • 0 §ه) , المحقق: السيد ابن عبد المقصود بن عبد الرحيم ,الناشر: دار الكتب العلمية - بيروت / لبنان. ـ تفسير القرآن العظيم (ابن كثير) ,المؤلف: أبو الفداء إسماعيل بن عمر بن كثير القرشي البصري ثم الدمثقي (المتوفى: عVVهـ) ,المحقق:

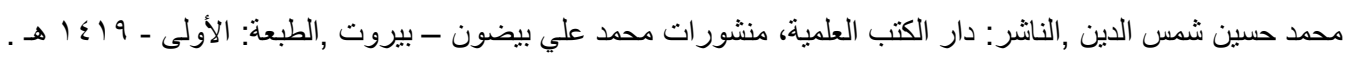

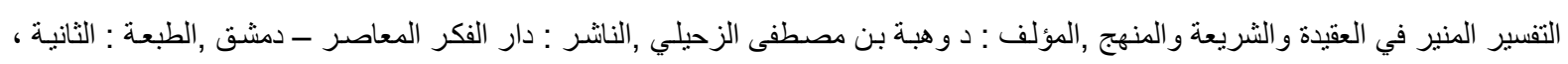
ه $1 \leqslant 1 \wedge$ ـ تفسير الماتريدي (تأويلات أهل السنة) المؤلف: محمد بن محمد بن محمود، أبو منصور الماتريدي (المنوفى: بساهـ)المحقق: د. مجدي باسلوم

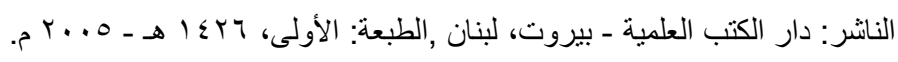

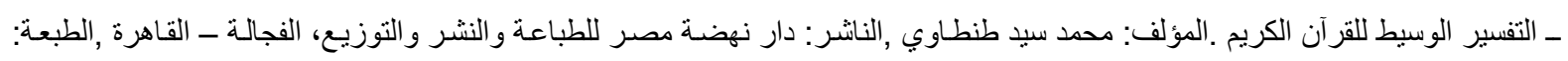

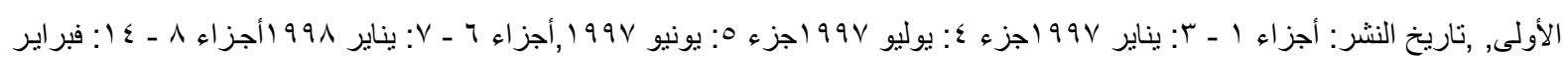

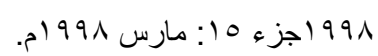

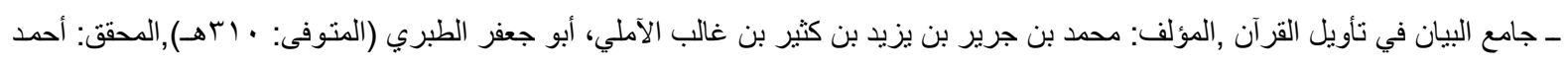

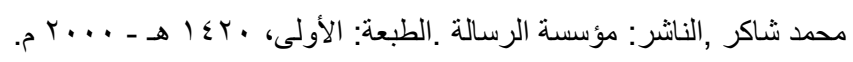

\section{- $\{\wedge$.}


- جو اهر البلاغة في المعاني والبيان و البديع ,المؤلف: أحمد بن إبراهيم بن مصطفى الهاثمي (المتوفى: بآباهـ) ,ضبط وتدقيق وتوثيق: د.

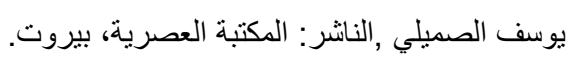

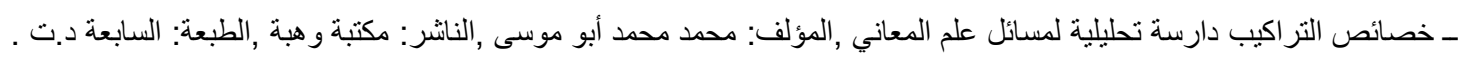

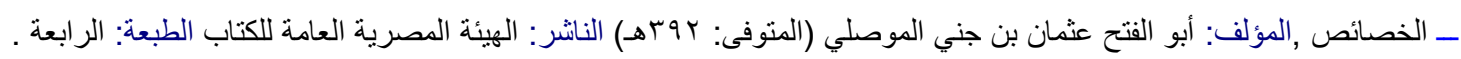

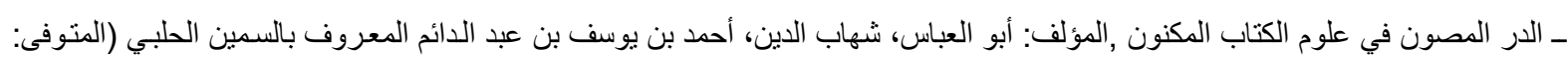

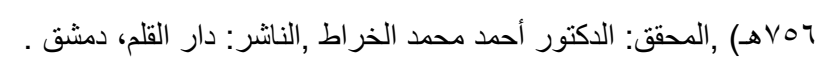

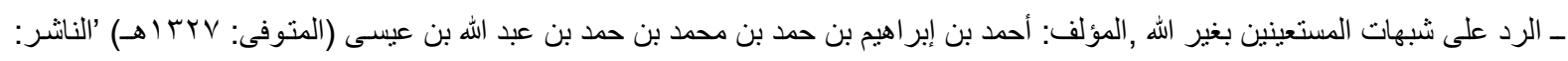

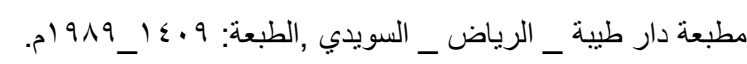

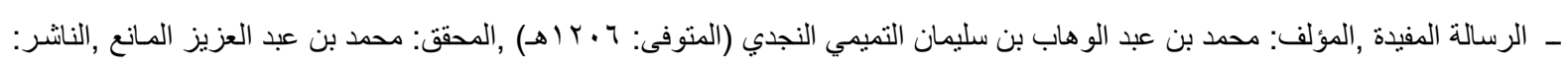

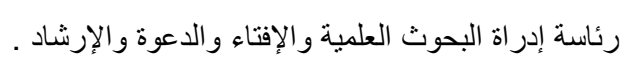

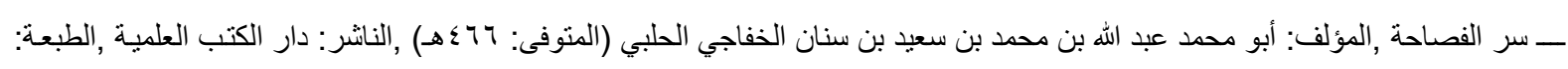

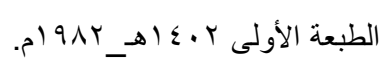

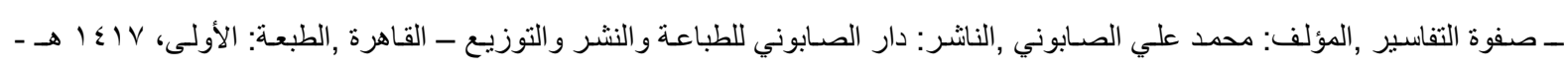
. $199 \mathrm{~V}$ - الصناعتين ,أبو هلال الحسن بن عبد الله بن سهل بن سعيد بن يحيى بن مهران العسكري (المتوفى: نحو ه9 هــ) ,المحقق: علي محمد

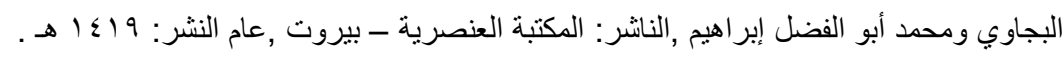

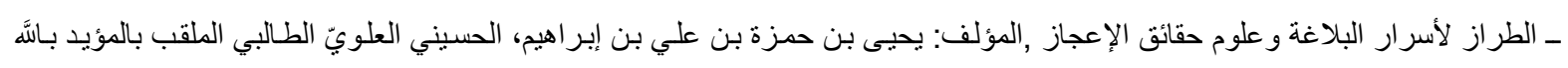

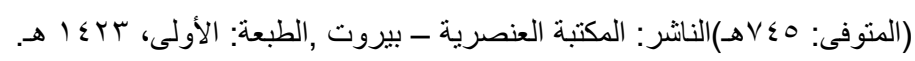

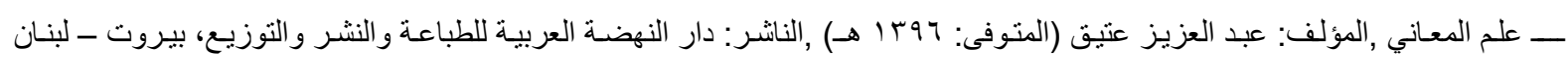

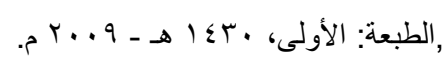

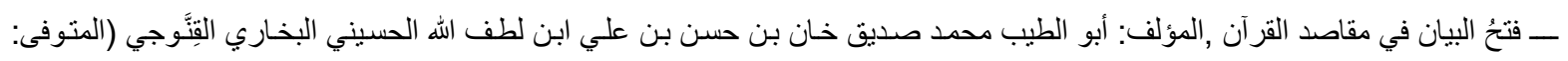

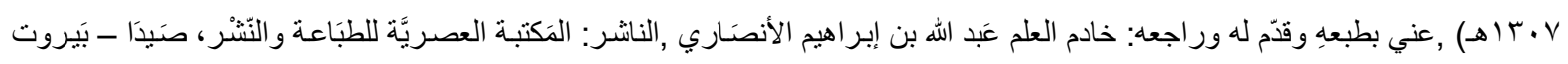

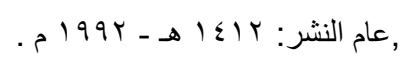

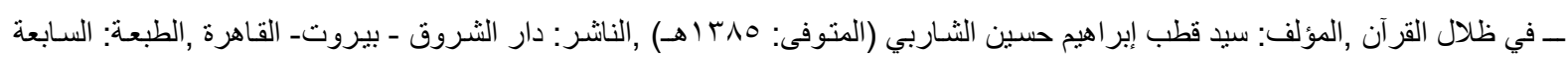

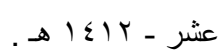
ـ الكتاب ,المؤلف: عمرو بن عثمان بن قنتبر الحارثي بالو لاء، أبو بشر، الملقب سييويه (المتوفى: ·11 اهـ) , المحقق: عبد السلام محمد هارون

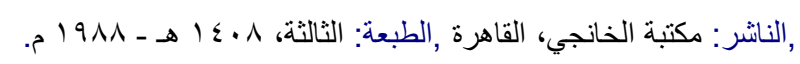

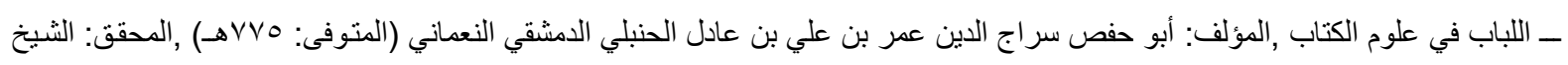

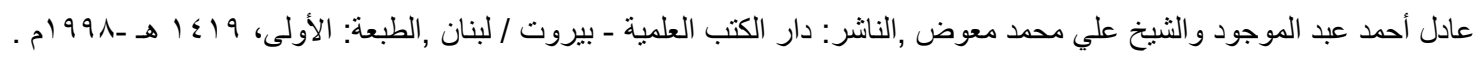

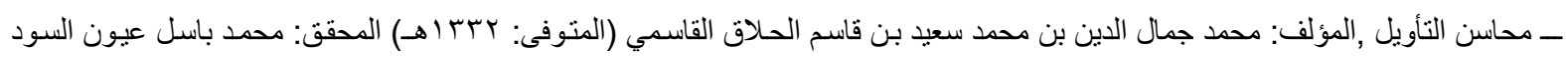

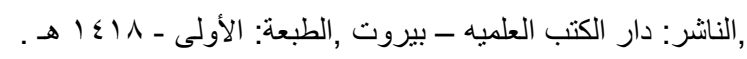

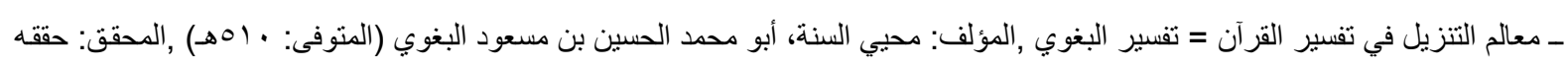

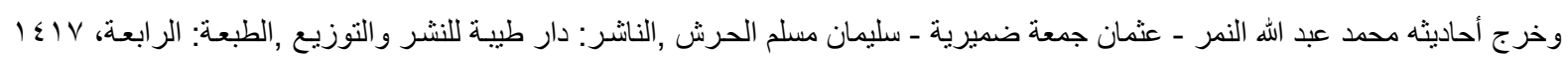
هـ - وخرجا لهادئه

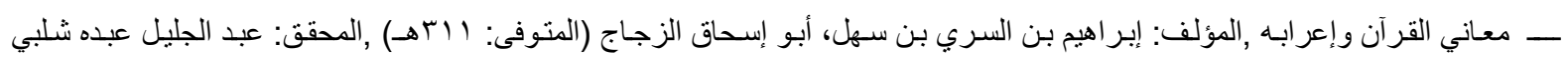

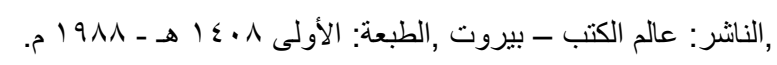

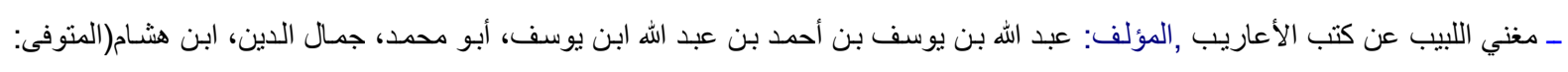

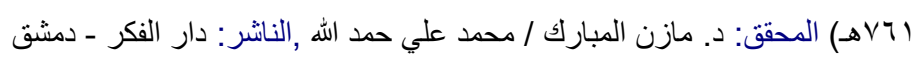


ـــ مفاتيح الغيب = التفسير الكبير ,المؤلف: أبو عبد الله محمد بن عمر بن الحسن بن الحسين التيمي الرازي الملقب بفخر الدين الرازي خطيب

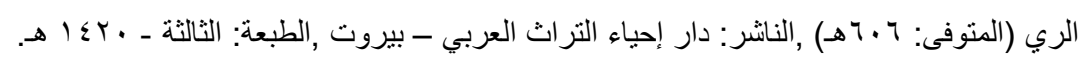

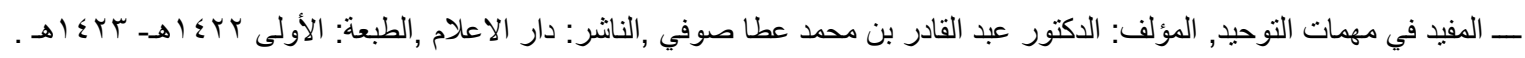

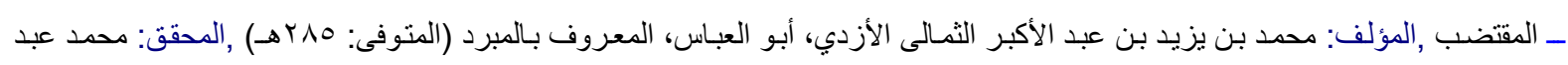

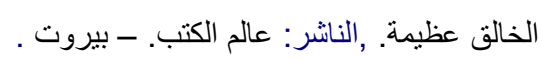
ـ القول السديد شرح كتاب التوحيد, المؤلف: أبو عبد الله، عبد الرحمن بن ناصر بن عبد الله بن ناصر بن حمد آل سعدي (المتوفى: جلاس إهـ) ,المحقق: المرتضى الزين أحمد ,الناشر: مجموعة التحف النفائس الدولية, الطبعة: الثالثة د.ت .

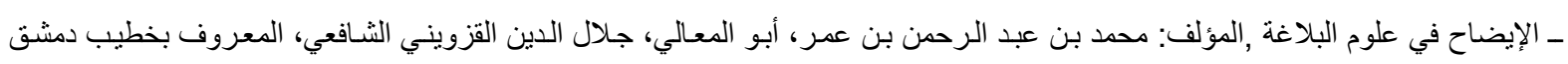

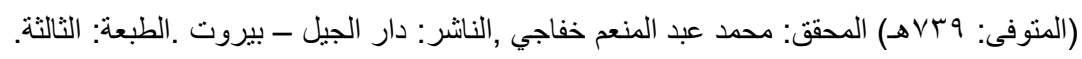


.01. 
